\title{
O Ensino Médio como Parcela do Direito ao MÍNIMO EXISTENCIAL ${ }^{1}$
}

\author{
Daniel Wunder Hachem* \\ Alan Bonat**
}

\begin{abstract}
1 Introdução. $2 \mathrm{O}$ regime jurídico dos direitos fundamentais na constituição de 1988 e a sua incidência sobre o direito à educação. 3 O direito ao mínimo existencial: definição e estrutura normativa. 4 A pretensão jurídica de acesso ao ensino médio: elemento integrante do mínimo existencial ou parcela do direito fundamental à educação que ultrapassa o seu núcleo essencial?. $5 \mathrm{O}$ poder judiciário e a pretensão de acesso ao ensino médio: análise da jurisprudência do stf e do tjrs. 6 Considerações finais. Referências.
\end{abstract}

\section{RESUMO}

Este artigo tem por objetivo analisar se o ensino médio, terceira etapa da educação básica, integra o direito ao mínimo existencial. Para tanto, são analisadas a estrutura normativa e o regime de proteção do direito fundamental à educação. $\mathrm{Na}$ sequência, apresenta-se uma definição do direito ao mínimo existencial, identificando que a sua estrutura normativa é de regra, insuscetível ao sopesamento. Após, tendo em vista a necessidade de definição do conteúdo do mínimo existencial, são analisadas distintas correntes a respeito de quais posições do direito fundamental à educação integram aquele direito, concluindo-se que de acordo com a Constituição brasileira de 1988, as finalidades e a relevância do ensino médio tornam essa

1 Artigo resultante de pesquisa realizada no marco do Projeto "Desenvolvimento e direitos fundamentais econômicos”, desenvolvida no NUPED - Núcleo de Pesquisas em Políticas Públicas e Desenvolvimento Humano do Programa de Pós-Graduação em Direito da PUCPR, com missão científica à Universidad Carlos III de Madrid para apresentação dos resultados financiada pela Chamada Pública n 17/2014-Fundação Araucária/CAPES.

* Professor dos Cursos de Graduação em Direito e dos Programas de Mestrado e Doutorado em Direito da Pontifícia Universidade Católica do Paraná e da Universidade Federal do Paraná (Curitiba-PR, Brasil). Doutor e Mestre em Direito do Estado pela Universidade Federal do Paraná. Vice-Líder do NUPED - Núcleo de Pesquisas em Políticas Públicas e Desenvolvimento Humano do PPGD-PUCPR. Diretor Acadêmico do NINC - Núcleo de Investigações Constitucionais do PPGD-UFPR. Coordenador Executivo, pelo Brasil, da Rede Docente Eurolatinoamericana de Derecho Administrativo. Membro do Foro Iberoamericano de Derecho Administrativo e da Asociación de Derecho Público del Mercosur. Advogado. Site: <www.danielhachem.com>. E-mail: <danielhachem@gmail.com>.

** Mestrando em Direito Econômico e Socioambiental pela Pontifícia Universidade Católica do Paraná - PUC/PR. Especialista em Direito e Processo Tributário pela Academia Brasileira de Direito Constitucional - ABDCONST. Graduado em Direito pelo Centro Universitário Curitiba - UNICURITIBA. Curitiba-PR, Brasil.E-mail: < bonat.alan@gmail.com>. 
etapa da educação imprescindível para a garantia da dignidade da pessoa humana. Ao final, o artigo examina o entendimento do Poder Judiciário, a partir de julgamentos proferidos pelo Supremo Tribunal Federal e pelo Tribunal de Justiça do Estado do Rio Grande do Sul, a respeito do ensino médio como parcela do mínimo existencial.

Palavras-chave: Direitos fundamentais. Direitos sociais. Mínimo Existencial. Educação Básica. Ensino Médio.

\section{INTRODUÇÃO}

A Constituição Federal prescreve, no artigo $3^{\circ}$, objetivos a serem perseguidos pela República Federativa do Brasil, como a construção de uma sociedade justa, a busca pelo desenvolvimento nacional, a redução das desigualdades sociais e regionais e a promoção do bem de todos. A educação é um importante meio para a persecução de tais metas constitucionais, tendo sido, por essa razão, elevada à condição de direito fundamental dos cidadãos no art. $6^{\circ}$ do texto constitucional.

Com a promulgação da Emenda Constitucional no 59/2009, foi alterada a amplitude dos deveres estatais no tocante à promoção da educação, passando a abranger todos os níveis da educação básica, quais sejam, a educação infantil, a educação fundamental e o ensino médio. Tais alterações reforçaram a importância do direito fundamental à educação ao aumentar as incumbências estatais voltadas à sua máxima realização.

Porém, além de ostentar um caráter instrumental em relação ao atingimento dos objetivos fundamentais da República (por ser um mecanismo necessário para alcançá-los), a educação possui uma importância intrínseca, na medida em que se encontra intimamente relacionada à dignidade da pessoa humana, pois permite que os indivíduos desenvolvam sua personalidade com autonomia e exerçam também outros direitos fundamentais, como as liberdades de comunicação, expressão e manifestação do pensamento, por exemplo. Portanto, é necessário que sejam asseguradas aos indivíduos ao menos as condições materiais para desfrutar dos níveis básicos da educação, permitindo-lhes com isso uma vida com dignidade.

Desse modo, o objetivo do presente artigo é analisar se o acesso ao ensino médio constitui uma condição necessária para garantir uma existência minimamente digna aos indivíduos, ou seja, se esta etapa da educação básica integra o direito ao mínimo existencial, ou se o ensino médio consiste em parcela do direito fundamental à educação que extrapola o conteúdo do mínimo existencial.

Para tanto, inicialmente serão delineadas as premissas que orientam este trabalho, identificando a estrutura normativa e o regime de proteção do direito à educação, na sua condição de direito fundamental. Após, buscar-se-á estabelecer uma definição sobre o direito ao mínimo existencial, comparando a estrutura normativa desse direito com a estrutura dos demais direitos fundamentais e 
demonstrando a necessidade de que esse direito apresente um conteúdo determinado. Em seguida, o estudo examinará se a pretensão de acesso ao ensino médio integra o mínimo existencial, a partir das finalidades específicas dessa etapa da educação. Com este propósito, será empreendida pesquisa eminentemente interdisciplinar, com o escopo de examinar qual é a real compreensão acerca das funções e da relevância do ensino médio para o desenvolvimento dos indivíduos. Por fim, será apresentado estudo jurisprudencial, com o intuito de averiguar qual o posicionamento do Poder Judiciário sobre a inclusão ou não do ensino médio como componente do mínimo existencial.

\section{O REGIME JURÍDICO DOS DIREITOS FUNDAMENTAIS NA CONS- TITUIÇÃO DE 1988 E A SUA INCIDÊNCIA SOBRE O DIREITO À EDUCAÇÃ̂}

O direito à educação é caracterizado no ordenamento jurídico brasileiro como um direito fundamental social, consoante se depreende do art. $6^{\circ}$ da Constituição Federal. Para uma adequada compreensão do mencionado direito fundamental, é necessário ter em mente a complexidade da estrutura normativa que tutela o direito à educação, bem como do regime jurídico de proteção desse direito. Além disso, faz-se também importante diferenciar o direito fundamental como um todo e as pretensões jurídicas que dele decorrem. Desse modo, a proposta deste tópico é delinear essas características peculiares aos direitos fundamentais, indicando as premissas sobre as quais se apoiará este estudo.

A Constituição Federal prescreve, em seu art. $1^{\circ}$, que o Estado brasileiro é um Estado Democrático de Direito, e que um de seus fundamentos é a dignidade da pessoa humana (art. $1^{\mathrm{o}}, \mathrm{III}, \mathrm{CF}$ ). Como consequência, os direitos fundamentais ostentam uma posição privilegiada no sistema normativo pátrio, uma vez que em maior ou menor medida decorrem da dignidade da pessoa e são essenciais para assegurar aos cidadãos uma existência livre e igualitária. ${ }^{1}$ Por essa razão, os direitos fundamentais integram o núcleo da Constituição material, juntamente com a "definição da forma de Estado, do sistema de governo e da organização do poder".

Tendo em vista a relevância dos direitos fundamentais nos Estados Democráticos de Direito contemporâneos, eles reclamam uma proteção mais vigorosa do sistema normativo, razão pela qual Constituições como a brasileira atribuem aos direitos dotados de jusfundamentalidade um regime jurídico especial. Essa condição peculiar - a jusfundamentalidade - visa a assegurar uma normatividade reforçada aos direitos fundamentais em relação às demais normas do ordenamento jurídico. ${ }^{3}$

A fundamentalidade formal se manifesta nos seguintes aspectos: (i) as normas de direitos fundamentais encontram-se no patamar mais elevado do ordenamento jurídico, tornando inválidas as disposições inferiores que lhes forem contrárias; (ii) como normas constitucionais, sua modificação requer 
um procedimento mais gravoso, sujeitando-se a limites formais de alteração; (iii) os direitos fundamentais representam limites materiais à reforma do texto constitucional; e (iv) são normas que representam parâmetros materiais de escolhas, decisões, ações e controles dos Poderes Públicos (Executivo, Legislativo e Judiciário). ${ }^{4}$

Neste ponto, importa destacar dois traços característicos deste regime jurídico especial, que distingue os direitos fundamentais dos demais direitos estabelecidos na Constituição Federal, quais sejam, a aplicabilidade imediata e a condição de cláusulas pétreas.

A aplicabilidade imediata é determinada pelo art. $5^{\circ}, \S 1^{\circ}$, da CF, e tem o condão de estabelecer que todas as disposições que consagram direitos e garantias fundamentais vinculam diretamente os Poderes Públicos. ${ }^{5}$ Isto significa que os direitos fundamentais produzem efeitos jurídicos imediatos, independentemente da sua regulamentação pelo legislador infraconstitucional, sendo possível que o titular do respectivo direito - a depender da pretensão jurídica em questão - possa exigi-lo administrativa ou judicialmente, ainda que com fundamento exclusivo na norma constitucional. ${ }^{6}$ No Direito brasileiro, essa aplicabilidade imediata é característica de todos os direitos fundamentais, não sendo exclusiva dos chamados "direitos de liberdade", 7 já que a própria redação do art. $5^{\circ}, \S 1^{\circ}$ faz alusão a "normas definidoras de direitos e garantias fundamentais", não estabelecendo nenhuma restrição. ${ }^{8}$

A segunda particularidade diz respeito à qualificação dos direitos fundamentais como cláusulas pétreas, em face do que prescreve o artigo $60, \S 4^{\circ}, \mathrm{IV}$, da Constituição Federal, o qual veda que seja "objeto de deliberação a proposta de emenda tendente a abolir: (...) os direitos e garantias individuais". Trata-se de um limite material à reforma constitucional e que abrange também os direitos sociais, pois, tanto quanto os ditos "direitos individuais", eles integram a essência da ordem constitucional brasileira, de modo que a supressão dos direitos sociais implicaria também uma violação ao princípio da dignidade da pessoa humana, limite material implícito à reforma do texto constitucional. ${ }^{9}$

Já a fundamentalidade material significa "que o conteúdo dos direitos fundamentais é decisivamente constitutivo das estruturas básicas do Estado e da sociedade"10. Assim, é possível reconhecer direitos como fundamentais em razão do seu conteúdo e importância, mesmo que estabelecidos fora do catálogo formal dos direitos fundamentais (Título II da Constituição Federal) ou não explicitamente prescritos pela CF. ${ }^{11}$ Essa consequência da fundamentalidade material é expressamente reconhecida pelo artigo $5^{\circ}, \S 2^{\circ}$, da Constituição brasileira, o qual preceitua que "Os direitos e garantias expressos nesta Constituição não excluem outros decorrentes do regime e dos princípios por ela adotados, ou dos tratados internacionais em que a República Federativa do Brasil seja parte”. Ademais, a esses direitos materialmente fundamentais aplica-se também o regime jurídico referente à fundamentalidade formal. 
Delineado o regime jurídico de proteção dos direitos fundamentais, impende analisar a estrutura das normas que tutelam estes direitos, a partir da dupla dimensão e das múltiplas funções dos direitos fundamentais.

No tocante à dupla dimensão, a norma que tutela o direito fundamental pode ser visualizada sob a perspectiva do titular do bem jurídico ou do objeto por ela tutelado. Na primeira, denominada dimensão subjetiva, a norma confere ao seu titular uma posição jurídica subjetiva, possibilitando assim que ele exija (administrativa ou judicialmente) determinada prestação do Poder Público destinatário da norma. ${ }^{12}$ É dizer, sob essa perspectiva, a norma de direito fundamental confere ao titular um "leque de possibilidades, que se encontram condicionadas à conformação concreta da norma que o consagra"13.

Por outro lado, a dimensão objetiva está relacionada aos deveres impostos ao Estado para que este resguarde e promova o direito fundamental tutelado sem a necessidade de que o titular o reclame. Assim, incumbe ao Poder Público criar condições reais e efetivas de fruição daquele bem jurídico pelos cidadãos, nos planos fático e jurídico, protegendo o titular do direito contra violações por parte do próprio Estado e de outros particulares, bem como criando estruturas que possibilitem o acesso a tais bens jurídicos fundamentais pelos cidadãos. Neste sentido, de acordo com Ingo Wolfgang Sarlet, a dimensão objetiva dos direitos fundamentais representa uma "ordem dirigida ao Estado no sentido de que a este incumbe a obrigação permanente de concretização e realização dos direitos fundamentais". ${ }^{14}$

A partir da conjugação dessa dupla dimensão das normas que tutelam os direitos fundamentais, pode-se observar tanto a multifuncionalidade dos direitos fundamentais, como a distinção entre o direito fundamental completo (ou "direito fundamental como um todo" ${ }^{15}$ ) e as diferentes pretensões jurídicas que ele reúne. ${ }^{16}$

Segundo Robert Alexy, um "direito fundamental completo é um feixe de posições de direitos fundamentais", e cada uma destas posições contempla funções de respeito, proteção e promoção, conferindo diferentes pretensões aos seus titulares e impondo deveres distintos ao Poder Público. ${ }^{17}$ Tais funções podem ser classificadas, inicialmente, em função de defesa e função de prestação. A função de prestação, por sua vez, é dividida em função de prestação fática e função de prestação normativa, e esta última é subdividida em função de proteção e função de organização e procedimento. ${ }^{18}$

A função de defesa impõe um dever de respeito ao bem jurídico fundamental, obrigando o Estado a abster-se e proibindo-o de praticar atos que violem o respectivo direito, ao passo que a função prestacional dirige ao Estado o dever de adotar medidas positivas para possibilitar o exercício do direito fundamental pelo seu titular. ${ }^{19}$ Esse aspecto prestacional exige que o Poder Público crie os "pressupostos fáticos e jurídicos necessários para o exercício dos direitos", podendo "se apresentar de variadas formas, conforme a natureza da prestação exigida pela norma de direito fundamental”. ${ }^{20}$ 
A função prestacional fática confere ao titular do direito fundamental a possibilidade de reivindicar em face do Poder Público algo que o cidadão poderia obter de outros particulares se dispusesse de recursos financeiros suficientes e se houvesse uma oferta disponível no mercado. ${ }^{21}$ Por outro lado, a função de prestação normativa diz respeito ao direito à elaboração de normas que resguardem determinados bens jurídicos nas hipóteses de eventuais violações por ações de terceiros, o que corresponde à função de proteção; ou ao direto à criação, pelo Poder Público, de organizações e procedimentos que auxiliem na promoção e na proteção dos direitos fundamentais (função de organização e de procedimento).

A partir da dupla dimensão (subjetiva e objetiva) e da multifuncionalidade dos direitos fundamentais, é possível estabelecer a distinção entre o direito fundamental à educação como um todo e as pretensões jurídicas que decorrem desse direito, as quais podem ser consideradas, cada qual, um direito fundamental em sentido estrito. Isso porque, se analisada a norma como um todo, a partir do conjunto de pretensões jurídicas por ela asseguradas, trata-se de um direito fundamental em sentido amplo; se tomada apenas uma das pretensões jurídicas dela emanadas, de forma isolada, cuida-se de um direito fundamental em sentido estrito (ou posição de direito fundamental). ${ }^{22}$

Dessa forma, se considerado o direito fundamental à educação em sentido amplo, ele engloba diversas pretensões jurídicas específicas, tais como: (i) a liberdade de aprender e ensinar, sendo defesa a imposição de métodos educacionais pelo Estado (função de defesa); (ii) a prestação de atendimento educacional especializado aos deficientes (função de prestação fática); (iii) a criação de órgãos e pessoas jurídicas que ofereçam gratuitamente o serviço público de educação (função de organização); (iv) a regulamentação de como se dará o acesso igualitário aos estabelecimentos públicos de ensino, tais como as universidades (função de procedimento); (v) a criação de normas que definam critérios de padrão de qualidade, bem como a sua fiscalização pelo órgão competente, para impedir que a exploração dessa atividade pelos particulares seja realizada abaixo dos níveis adequados (função de proteção). Nos exemplos citados, cada uma dessas pretensões jurídicas pode ser identificada em um dispositivo específico da Constituição Federal (art. 206, I, II, IV, VII e art. 208, III).

Isto posto, salienta-se que o presente artigo dedicará as próximas páginas não ao direito à educação em sentido amplo, mas especificamente à pretensão jurídica de acesso ao ensino médio (terceira etapa da educação básica), a fim de analisar se essa posição de direito fundamental integra ou não o mínimo existencial.

\section{O DIREITO AO MÍNIMO EXISTENCIAL: DEFINIÇÃO E ESTRU- TURA NORMATIVA}

Em razão da estrutura normativa complexa das normas que tutelam os direitos fundamentais (dupla dimensão - subjetiva e objetiva - e multifuncionalidade), incumbe ao Poder Público criar as condições fáticas e jurídicas 
para a realização destes direitos, observando os deveres de respeito, proteção e promoção. Essa atuação estatal deve ser orientada à satisfação maximizada de todos os direitos fundamentais, promovendo assim de maneira otimizada a dignidade da pessoa humana. ${ }^{23}$ Isso porque o Estado e os seus aparatos devem ser compreendidos como um meio, cujo fim é proporcionar o bem-estar dos cidadãos por meio da plena fruição dos direitos fundamentais. ${ }^{24}$

Em que pese a existência de tais deveres, na realidade fática, nem sempre os Poderes Públicos logram atender eficazmente aos comandos constitucionais, razão pela qual, conforme a intensidade da proteção e da promoção dos direitos fundamentais empreendidas pelo Estado, a dignidade da pessoa humana pode ser promovida em maior ou menor grau. Ainda que possa haver divergências quanto ao conteúdo e à extensão do princípio da dignidade humana, entende a doutrina ser "possível identificar uma linha abaixo da qual não há dignidade". 25 É dizer, existe um conjunto de condições mínimas necessárias para que os cidadãos tenham uma existência minimamente digna, que engloba tanto condições de liberdade (por exemplo, liberdade de manifestação do pensamento), quanto condições materiais, as quais pressupõem prestações normativas e fáticas. ${ }^{26}$ Convencionou-se denominar esse conjunto de condições mínimas para uma existência digna de direito ao mínimo existencial, o qual corresponde ao núcleo material do princípio da dignidade da pessoa humana. ${ }^{27}$

No tocante às condições materiais, de acordo com Daniel Sarmento, o direito ao mínimo existencial ostenta duas dimensões, uma negativa e uma positiva. Em sua vertente negativa, ele impõe um limite à pratica de atos pelo Estado que tolham as condições materiais imprescindíveis para uma vida digna. Por outro lado, a dimensão positiva do direito ao mínimo existencial envolve um conjunto essencial de direitos prestacionais, incumbindo ao Poder Público fornecer essas condições materiais mínimas aos cidadãos. ${ }^{28}$ Note-se que o Poder Público não deve se limitar a fornecer as prestações que componham o mínimo existencial; este deve ser compreendido como um piso mínimo dos direitos fundamentais a ser promovido pelo Estado. ${ }^{29}$

Ademais, ressalta-se que o direito ao mínimo existencial, como "conjunto de bens e utilidades básicas para a subsistência física e indispensável ao desfrute da própria liberdade", 30 não se limita ao fornecimento de prestações que garantam a mera sobrevivência física dos indivíduos, o que corresponderia ao chamado "mínimo vital". O direito ao mínimo existencial compreende também prestações que possibilitem ao indivíduo usufruir de outros direitos fundamentais, desenvolver sua personalidade e participar das deliberações públicas. $\mathrm{Ou}$ seja, o mínimo existencial engloba um mínimo vital e, para além deste, também um mínimo sociocultural. ${ }^{31}$

A partir da análise do direito ao mínimo existencial sob a perspectiva positiva, o Poder Público encontra-se vinculado ao dever de fornecimento das condições materiais que permitam uma existência minimamente digna. Em caso de eventual violação ao mínimo existencial pela prática de atos omissivos, é pos- 
sível que o titular da pretensão jurídica postule judicialmente a condenação do Poder Público ao oferecimento de determinada prestação. Essa justiciabilidade dos direitos fundamentais não se restringe à parcela desses direitos que integra o núcleo do princípio da dignidade humana, ${ }^{32}$ mas em razão da destacada importância do direito ao mínimo existencial, este apresenta estrutura normativa de regra, diferentemente da estrutura de princípio que, usualmente, apresentam os direitos fundamentais.

Segundo Robert Alexy, a diferença entre regras e princípios, espécies do gênero norma, é uma diferença de estruturas normativas (diferença qualitativa). Os princípios são ordens prima facie de decidir, pois determinam que algo seja realizado na maior medida possível, considerando-se as possibilidades fáticas e jurídicas existentes e, portanto, podem ser satisfeitos em graus diferentes. Sua aplicação, em casos de colisão, ocorre pela forma de ponderação. Por outro lado, as regras expressam ordens definitivas de decidir: se for válida e a situação fática analisada se amoldar à hipótese de incidência nela descrita, a regra se aplica em sua totalidade, não admitindo satisfação em graus distintos e não se sujeitando à ponderação. ${ }^{33}$

Por ostentar a natureza de regra, a norma que tutela o direito ao mínimo existencial deve ser aplicada por subsunção, razão pela qual a exigibilidade judicial do referido direito não está sujeita a ponderações. ${ }^{34}$ Isso porque a construção do mínimo existencial, ao precisar as condições materiais mínimas para resguardar o núcleo do princípio da dignidade, já é fruto de ponderação entre outros direitos fundamentais e demais normas constitucionais, o que significa que o mínimo existencial é um direito definitivo. ${ }^{35}$

Duas consequências podem ser inferidas a partir da compreensão do mínimo existencial como um direito definitivo: (a) como não está sujeito à ponderação, sua justiciabilidade também não está subordinada à reserva do possível; e (b) para que o conceito seja útil, seu conteúdo deve ser previamente identificado a partir de um rol constitucional preferencial, não sendo adequado supor que a sua identificação se dará de forma totalmente variável e aleatória em cada caso concreto.

(a) A teoria da reserva do possível, apesar de no Brasil ser usualmente associada somente à capacidade financeira do Estado (uma reserva do financeiramente possível), na verdade diz respeito à razoabilidade de uma pretensão individual em face de interesses coletivos, ostentando três dimensões: (i) dimensão negativa, que corresponde especificamente à razoabilidade da pretensão; (ii) dimensão fática, a qual diz respeito à insuficiência de recursos fáticos para a satisfação de uma pretensão; e (iii) dimensão jurídica, que diz respeito à indisponibilidade e incapacidade jurídica para se dispor de recursos existentes, cujo exemplo mais comum é a inexistência de previsão de determinada despesa na lei orçamentária. ${ }^{36}$ Ocorre que em nenhuma dessas três dimensões o argumento da reserva do possível é oponível ao direito ao mínimo existencial. 
Em relação à (i) razoabilidade, tendo em vista que o mínimo existencial engloba apenas as prestações necessárias para prover uma vida minimamente digna (e não aquelas necessárias à satisfação integral e maximizada dos direitos fundamentais sociais), qualquer pretensão albergada pelo direito ao mínimo existencial será razoável por se tratar de um patamar mínimo e imprescindível. A problemática, aqui, é identificar se a pretensão em questão de fato integra o mínimo existencial, pois se tudo puder ser incluído nesse direito de acordo com o caso concreto, a afirmação acima perde o sentido, o que corrobora a necessidade de que esse direito tenha seu conteúdo bem delineado e identificável previamente a partir de pautas constitucionais prioritárias. ${ }^{37}$

Em relação à (ii) dimensão fática da reserva do possível, Mônia Clarissa Hennig Leal e Iuri Bolesina aduzem que é possível sujeitar o mínimo existencial à reserva do possível quando a escassez for natural (pura) e comprovada, pois neste caso não "haverá o que ser feito para solucionar o atendimento do mínimo existencial ou o seu atendimento parcial". Contudo, apontam duas ressalvas. Inicialmente, uma escassez quase-natural não pode ser oposta ao mínimo existencial, pois ela poderia ser solucionada por ações do Estado e/ou da sociedade de incentivo ao suprimento da escassez. Além disso, afirmam que uma situação de escassez financeira fática é praticamente impossível, tendo em vista que as possibilidades de crédito e de extração de dinheiro público, pelo Estado, são praticamente ilimitadas. ${ }^{38}$

Apesar de tais argumentos, entende-se aqui que os recursos financeiros do Estado não são ilimitados, pois é possível que em sociedades com baixo índice de desenvolvimento humano e econômico o atendimento ao mínimo existencial de todos os que necessitam implique insuficiência de recursos para atender todas as necessidades. Contudo, justamente em um cenário como este o mínimo existencial deve ter uma proteção reforçada, haja vista que se há insuficiência de recursos para garantir as condições mínimas para uma vida digna aos cidadãos de uma determinada sociedade é porque houve eleição equivocada na ordem de prioridades de emprego dos recursos públicos, de sorte que mesmo essa dimensão fática não retira a natureza de regra do direito ao mínimo existencial e tampouco prejudica sua justiciabilidade. ${ }^{39}$

Em relação à (iii) dimensão jurídica da reserva do possível, ela não inviabiliza a justiciabilidade do mínimo existencial e tampouco afasta sua natureza de regra. Existindo recursos financeiros para que o Poder Público assegure as condições materiais mínimas aos cidadãos, tais recursos devem ser utilizados para tanto. Se não houve previsão orçamentária para assegurar estas condições materiais mínimas, ou se tais valores foram destinados para outros fins, novamente houve equívoco na escolha da alocação dos recursos públicos diante de uma prioridade máxima fixada na Constituição Federal.

Portanto, são sempre exigíveis judicialmente as condições materiais (sejam prestações normativas ou fáticas) destinadas à realização das parcelas 
dos direitos fundamentais que compõem o mínimo existencial, não podendo ser oposto a esta exigibilidade o argumento da reserva do possível.

(b) No tocante ao conteúdo do mínimo existencial, certamente não há como supor que se trate de um conceito absolutamente estático, permanente no tempo e no espaço, formado por um conjunto imutável de direitos que todos os indivíduos já necessitaram, necessitam e sempre necessitarão em qualquer momento histórico e em qualquer realidade social. O seu conteúdo será distinto conforme o contexto histórico de cada povo, em cada Estado, ${ }^{40}$ pois as "condições necessárias à existência digna variam de acordo com o tempo e espaço, o desenvolvimento econômico, social e cultural de cada sociedade". ${ }^{41}$

Isso não significa, contudo, que o conteúdo do direito ao mínimo existencial seja totalmente variável em cada caso concreto, passível de identificação em cada situação pelo Poder Judiciário, a partir das necessidades individuais de quem postula determinada prestação. Em que pese haja significativa parcela da doutrina que sustente tal posição, ${ }^{42}$ entende-se mais adequado traçar, à luz das prioridades estabelecidas pela Constituição Federal, um conteúdo concreto deste direito previamente identificável, uma vez que aceitar um conceito completamente aberto de mínimo existencial, suscetível a variações indiscriminadas da sua especificação ao sabor do intérprete, a depender do caso concreto, prejudica a funcionalidade operacional do instituto.

A problemática de um conceito indeterminado e amplo reside na possibilidade de se enquadrar no direito ao mínimo existencial diversas pretensões que extrapolam as condições mínimas para uma existência digna ou de se afirmar que determinadas posições jurídicas essenciais não se encontram por ele abrangidas, confundindo-se assim o conceito de dignidade da pessoa humana com o de mínimo existencial. Se o conteúdo desse último só pudesse ser identificado pelo juiz no caso concreto, bastaria que o magistrado invocasse o princípio da dignidade da pessoa humana e afirmasse que o seu conteúdo foi violado, sendo despiciendo falar em "mínimo existencial". A razão pela qual a doutrina e a jurisprudência brasileiras importaram essa categoria do Direito alemão foi justamente para tentar identificar um núcleo material da dignidade da pessoa humana insuscetível de ponderação e restrição, como forma de fortalecer esse princípio e evitar o seu afastamento nas situações concretas. Sem especificar com precisão o conteúdo concreto desse direito de antemão, sua funcionalidade perde todo o valor, pois ele acaba sendo deixado à mercê de manipulações argumentativas sobre o seu conteúdo em cada caso.

Mas não é só. Admitir que a identificação do conteúdo do mínimo existencial deva ser feita a partir das necessidades dos indivíduos em cada caso concreto possibilitaria que fossem criadas distinções sobre as condições mínimas para uma existência digna de maneira anti-isonômica. Tal entendimento não resiste a uma interpretação sistemática do texto constitucional, pois permitiria um tratamento desigual a cidadãos que se encontram em situações idênticas, contrariando o direito fundamental à igualdade (art. $5^{\circ}$, caput da $C F$ ) e a previsão do art. $5^{\circ}, \mathrm{XLI}$, segundo a qual "a lei punirá qualquer discriminação 
atentatória aos direitos e liberdades fundamentais". Por essa razão, entende-se necessário que seja delineado um conteúdo do direito ao mínimo existencial, o que pode ser feito identificando-se na ordem constitucional de cada Estado, em determinado momento histórico, quais são as condições essenciais para que todos os cidadãos possam usufruir de uma vida minimamente digna.

Desse modo, visando a contribuir para a definição do conteúdo do direito ao mínimo existencial em matéria de educação no Direito Constitucional brasileiro contemporâneo, buscar-se-á, no próximo tópico, examinar quais das pretensões jurídicas de acesso aos diferentes níveis da educação básica integram o mínimo existencial, por serem imprescindíveis para que os cidadãos tenham uma vida minimamente digna.

\section{A PRETENSÃO JURÍDICA DE ACESSO AO ENSINO MÉDIO: ELE- MENTO INTEGRANTE DO MÍNIMO EXISTENCIAL OU PARCELA DODIREITOFUNDAMENTAL À EDUCAÇÃOQUEULTRAPASSAO SEU NÚCLEO ESSENCIAL?}

O direito fundamental à educação é previsto de forma bastante detalhada na Constituição Federal, a qual começa por enunciá-lo entre os direitos sociais em seu art. $6^{\circ}$. Em relação às competências legislativas para disciplinar a matéria, o constituinte conferiu à União Federal a prerrogativa para legislar sobre o tema definindo as diretrizes e bases da educação nacional (art. 22, XXIV) e atribuiu competência concorrente a todos os entes federativos para legislarem sobre o assunto (art. 24, IX). Quanto às competências administrativas para a implementação do direito em questão, a Constituição impõe a todos os entes da federação o dever de proporcionar os meios de acesso dos cidadãos à educação, nos termos do art. 23, V.

No "Título VIII - Da Ordem Social", o texto constitucional especificou de forma significativa o conteúdo do direito fundamental à educação entre os artigos 205 e 214. Tais dispositivos são regulamentados pela legislação infraconstitucional, essencialmente pela Lei no 9.394/1996 (Lei de Diretrizes e Bases da Educação Nacional - LDB). Importante ressaltar neste ponto que as normas infraconstitucionais que se destinam a regulamentar e delinear os contornos do direito fundamental à educação também integram o seu conteúdo, razão pela qual se pode dizer que o conteúdo das normas que tutelam o referido direito é formado pela interpretação extraída da conjugação de enunciados constitucionais e infraconstitucionais, o que é bem explicado por Jorge Reis Novais.

Segundo o autor, as relações entre direitos fundamentais, Constituição e lei são complexas, existindo entre estas duas últimas uma espécie de circularidade, pois "se é certo que o legislador se encontra diretamente vinculado à observância dos direitos fundamentais, em contrapartida, o acesso aos bens objecto da protecção jusfundamental depende muitas vezes, e decisivamente, da actividade criadora ou conformadora do Estado e, particularmente, do legislador". ${ }^{43}$ 
Dessa forma, se a norma extraída exclusivamente dos enunciados constitucionais for aberta, ela permitirá somente a identificação daquilo que, a princípio (prima facie), está contido ou excluído do âmbito de proteção do direito fundamental. Nessa hipótese, quando há a edição de uma lei acrescentando novas condições e restrições, ou esclarecendo o conteúdo do respectivo direito fundamental, essa disposição infraconstitucional altera a própria norma de direito fundamental. Por conseguinte, as normas infraconstitucionais compõem, em conjunto com as normas constitucionais que as regulamentam, uma unidade sistemática entre "direito da constituição" e "direito da lei", o que resulta na jusfundamentalidade também das normas legais. ${ }^{44}$

Depreende-se do art. 205 da Constituição Federal que a educação é um direito de todos e um dever do Estado e da família, tendo como objetivo assegurar ao cidadão seu pleno desenvolvimento, seu preparo para o exercício da cidadania e a sua qualificação para o trabalho. Os deveres estatais em relação à educação são determinados pelo art. 208, dentre os quais merece atenção o inciso I, o qual determina que o Poder Público garanta a "educação básica obrigatória e gratuita dos 4 (quatro) aos 17 (dezessete) anos de idade, assegurada inclusive sua oferta gratuita para todos os que a ela não tiveram acesso na idade própria”, mas sem estabelecer os níveis educacionais que compõem a chamada "educação básica". Tendo em vista essa indeterminação do dispositivo constitucional, extrai-se a definição da "educação básica" do artigo 21, I, da Lei no 9.394/1996, segundo o qual a educação básica compreende três níveis de educação: (i) educação infantil; (ii) ensino fundamental; e (iii) ensino médio.

Observa-se que inciso I, do art. 208, acima mencionado, foi modificado pela Emenda Constitucional no 59/2009, pois, anteriormente à sua promulgação, o Estado tinha o dever de garantir a todos somente o acesso ao ensino fundamental, cabendo-lhe, em relação ao ensino médio, promover o acesso de forma progressiva. ${ }^{45}$ Essa alteração foi importante, porquanto realiza o compromisso do Estado brasileiro de implementar progressivamente a educação "secundária", 46 assumido quando da adesão ao Pacto Internacional sobre Direitos Econômicos, Sociais e Culturais (o qual foi introduzido no ordenamento jurídico interno pelo Decreto $n^{\circ}$ 591/1992).

A partir dessa breve exposição sobre os dispositivos constitucionais e infraconstitucionais acerca da educação básica, uma primeira questão a ser enfrentada é: o direito fundamental à educação integra o mínimo existencial? Não há maiores dificuldades em responder essa indagação, na medida em que há certo consenso de que, na sistemática constitucional brasileira, sem algum nível de educação não há como os indivíduos terem uma vida minimamente digna. ${ }^{47}$ Porém, se é certo que o direito fundamental à educação compõe o mínimo existencial, não se pode afirmar que todo o seu conteúdo, em sua máxima extensão, faz parte desse mínimo. Não é o direito fundamental à educação "como um todo" que faz parte do mínimo existencial, mas apenas aquelas parcelas - posições ou pretensões jurídicas fundamentais - dele decorrentes, que se 
mostrem efetivamente imprescindíveis para que o indivíduo possua condições materiais mínimas de viver com dignidade.

Tome-se como exemplo o acesso às universidades (educação superior). Ele faz parte do direito fundamental à educação e está assegurado no art. 208, V da Constituição, quando prevê que é dever do Estado com a educação a garantia de "acesso aos níveis mais elevados do ensino, da pesquisa e da criação artística, segundo a capacidade de cada um". Seria demasiado, no entanto, afirmar que sem um diploma de ensino superior seria impossível viver de forma minimamente digna no Brasil. É evidente que quanto mais elevada a formação do cidadão, melhores posições sociais a pessoa poderá galgar, ampliando as possibilidades de se viver de forma digna, mas quando se trata do direito ao mínimo existencial, está-se analisando quais condições são realmente indispensáveis para se viver com um mínimo de dignidade. Logo, o acesso à educação superior consiste em uma posição jurídica assegurada pelo direito fundamental à educação, ostentando assim caráter jusfundamental e gozando do regime jurídico aplicável a tais direitos, mas não integra, todavia, o conteúdo do direito ao mínimo existencial.

É possível encontrar ao menos duas correntes distintas sobre quais etapas da educação integram o direito ao mínimo existencial. A primeira sustenta que somente as pretensões de acesso à educação infantil e ao ensino fundamental integram o mínimo existencial, ao passo que a segunda defende que o direito ao mínimo existencial alberga o acesso a todos os níveis da educação básica, incluindo o ensino médio.

A maior parte dos autores filia-se à primeira corrente, entendendo que somente os dois primeiros níveis da educação básica (educação infantil e ensino fundamental) integram o direito ao mínimo existencial, de sorte que o ensino médio estaria enquadrado como uma parcela do direito fundamental social à educação que extrapola o conteúdo do mínimo existencial. É o caso de Cláudio Pereira de Souza Neto, Elaine Ferreira de Souza, Felipe de Melo Fonte, Caio Ramon Guimarães de Oliveira, Iuri Bolesina e Mônia Clarissa Hennig Leal, Erinaldo Ferreira do Carmo e Enivaldo Carvalho da Rocha. ${ }^{48}$ Faz-se necessária aqui uma observação: apesar de todas as obras consultadas terem sido publicadas após 2010 (e, portanto, posteriormente à promulgação da EC nº 59/2009), alguns dos autores citados, ao aduzirem que somente a educação infantil e fundamental integram o mínimo existencial para concluir que o Estado teria a obrigatoriedade de garantir apenas estes níveis da educação básica, tomam como referência a redação do art. 208, I da CF anterior à promulgação da referida Emenda Constitucional. ${ }^{49}$

É preciso observar que, após a promulgação da EC n ${ }^{\circ}$ 59/2009, não há que se falar em dever do Estado em assegurar exclusivamente a educação fundamental e a educação infantil. A Constituição Federal prevê expressamente a necessidade de que seja garantido o acesso a todos os níveis da educação básica, independentemente de se associar tal dever estatal ao mínimo existencial, afinal, em momento algum o texto constitucional se refere ao mínimo existencial ou 
o utiliza como condição de exigibilidade judicial de prestações estatais ligadas a direitos sociais. Em outras palavras: não há fundamento jurídico para supor que incumbe ao Estado proporcionar aos cidadãos somente as parcelas dos direitos sociais que integram o mínimo existencial, pois o conteúdo de tais direitos, disciplinado pela Constituição Federal, impõe claramente deveres ao Poder Público que extrapolam o mínimo existencial.

Ademais, apesar de realmente não ser indigno exercer qualquer profissão que não exija "conhecimentos construídos no ensino médio", tal afirmação é insuficiente para excluir a terceira etapa da educação básica do mínimo existencial, pois restringe a finalidade do ensino médio à qualificação profissional, deixando de avaliar se o ensino médio é uma condição imprescindível para que os cidadãos possam desenvolver plenamente suas personalidades, participar das decisões públicas, usufruir de outros direitos fundamentais e, consequentemente, ter uma existência minimamente digna.

Sob outra perspectiva, Ana Paula de Barcellos e Guilherme Piccina expressam concordância com a segunda corrente antes mencionada, qual seja, aquela que defende que todas as etapas da educação básica como um todo (educação infantil, educação fundamental e ensino médio) compõem o mínimo existencial. ${ }^{50}$

O argumento principal apresentado por Ana Paula de Barcellos é a própria alteração introduzida pela $\mathrm{EC} \mathrm{n}^{\circ}$ 59/2009: tendo em vista que o poder reformador impôs ao Estado o dever constitucional de garantir a educação básica como um todo, esta passaria a integrar o mínimo existencial..$^{51} \mathrm{Em}$ um segundo momento, a autora busca fundamentar a inclusão do ensino médio no mínimo existencial a partir de elementos infraconstitucionais, especificamente as Leis $n^{0} 10.172 / 2001$ e $n^{0} 11.096 / 2005$, e o Decreto $n^{0} 6.096 / 2007$. Tais diplomas normativos infraconstitucionais preveem, em síntese, a ampliação do acesso ao ensino superior. Como a Constituição Federal prescreve como prioridade, em matéria de educação, a promoção da educação básica, a partir do momento em que o Poder Legislativo reconheceu a possibilidade de "investir de forma relevante na expansão do ensino superior" seria possível concluir, segundo Barcellos, que a educação básica (e, portanto, o ensino médio) já está sendo promovida de forma adequada e satisfatória pelo Poder Público. Isso porque - afirma a autora - "não faria sentido, considerando o sistema constitucional, que o Poder Público pudesse investir em níveis superiores de ensino e não se pudesse exigir dele o fornecimento do ensino básico, descrito pela Constituição como obrigatório". 52

Apesar de os argumentos acima expostos avançarem na construção do direito ao mínimo existencial, são necessárias duas considerações sobre eles. No tocante à alteração promovida pela $\mathrm{EC} \mathrm{n}$ n $^{\circ}$ 59/2009, repise-se que, se considerado isoladamente, o fato de a Constituição Federal determinar ao Estado o dever de assegurar o acesso à educação básica não é suficiente para afirmar que o mínimo existencial alberga o referido direito. Afinal, o critério para saber se 
determinada prestação integra ou não o mínimo existencial não é a existência ou não de dever constitucional imposto ao Estado para fornecer tal prestação. Há incumbências estatais que, embora decorram de comandos constitucionais expressos e sejam de cumprimento obrigatório, não fazem parte do direito ao mínimo existencial. Logo, essa correlação entre existir exigência constitucional de formecimento de acesso ao ensino médio (inserida pela EC no 59/2009) e o acesso ao ensino médio integrar o mínimo existencial por conta disso não faz sentido.

Por outro lado, apesar de se concordar com as afirmações de Ana Paula de Barcellos de que o acesso ao ensino médio é exigível judicialmente (pois o dever estatal de proporcioná-lo foi claramente imposto pela nova redação constitucional) e de que as políticas públicas de fomento ao ensino superior são um indicativo da importância do ensino médio no ordenamento jurídico brasileiro, não é possível concluir que essa etapa da educação básica esteja sendo oferecida adequadamente aos cidadãos. Pelo contrário, depreende-se de pesquisa realizada pelo Instituto Brasileiro de Geografia e Estatística - IBGE, que, em 2011, apenas 50\% dos jovens de 15 a 17 anos frequentava o ensino médio, e a taxa média de abandono escolar precoce representava aproximadamente $32 \%$ (trinta e dois por cento) das pessoas entre 18 e 24 anos. ${ }^{53}$

Desse modo, entende-se mais adequada a proposta apresentada por Guilherme Piccina, a qual busca fundamentar a educação básica como componente do mínimo existencial a partir das finalidades da educação na sistemática constitucional. Nesse sentido, segundo o autor, a educação básica tem como objetivos: assegurar ao cidadão seu pleno desenvolvimento, seu preparo para o exercício da cidadania e sua qualificação para o trabalho (art. 205); garantir "a cada pessoa o desenvolvimento das capacidades e aptidões físicas, morais e intelectuais", as quais estão relacionadas ao núcleo material do princípio da dignidade da pessoa humana $\left(\right.$ art. $\left.1^{\mathrm{O}}, \mathrm{III}\right)$; permitir que cada pessoa participe das decisões públicas, proporcionando-lhe assim a cidadania (art. $1^{\circ}$, II); e servir como instrumento para realizar os objetivos constitucionais de promoção do bem de todos, erradicação da pobreza e redução das desigualdades sociais e regionais (art. $3^{\circ}$, III e IV). ${ }^{54}$

Considerando essas finalidades da educação (em sentido amplo) como ponto de partida, é possível analisar a função desempenhada pelo ensino médio a partir dos objetivos específicos atribuídos a essa etapa da educação básica. É dizer, se o ensino médio for necessário para atingir os objetivos acima mencionados, ele será imprescindível para garantir aos cidadãos uma vida minimamente digna e, portanto, integrará o mínimo existencial.

O artigo 35, da Lei de Diretrizes e Bases da Educação Nacional, ${ }^{55}$ atribui quatro finalidades ao ensino médio: (i) consolidar e aprofundar os conhecimentos adquiridos pelo cidadão no ensino fundamental, de modo que ele possa prosseguir com seus estudos; (ii) oferecer as condições básicas para o trabalho e para a cidadania do educando; (iii) permitir o aprimoramento do cidadão como pessoa humana, proporcionando a formação ética, o desenvolvimento 
da autonomia intelectual e o desenvolvimento do pensamento crítico; e (iv) possibilitar ao educando a percepção "dos fundamentos científico-tecnológicos dos processos produtivos”, visando à integração entre teoria e prática.

Entre tais objetivos, destaca-se inicialmente o reconhecimento, pelo ordenamento jurídico, de que somente no ensino médio o educando será preparado para o exercício da cidadania, salientando-se a importância desta etapa da educação básica dentro dos objetivos gerais da educação na sistemática constitucional brasileira (art. 205, da CF). Isso porque, de acordo com a LDB, não há qualquer menção à preparação para a cidadania como fins da educação infantil ${ }^{56}$ ou do ensino fundamental. ${ }^{57}$ Desse modo, verifica-se uma intrínseca relação entre o ensino médio e a cidadania, um dos fundamentos da República Federativa do Brasil (art. 1 ${ }^{\mathrm{O}}$, II, CF).

Nessa linha, pesquisa empírica coordenada por Miriam Abramovay e Mary Garcia Castro sobre as finalidades do ensino médio na sociedade brasileira elucida bem a importância dessa etapa da educação básica. Na mencionada investigação, foram entrevistados docentes e estudantes do ensino médio em diversos Estados membros da federação brasileira, com o escopo de examinar qual a relevância do ensino médio para os indivíduos. Um dos grupos de professores entrevistados atribuiu ao ensino médio a finalidade de proporcionar aos cidadãos uma "formação consciente para que saibam pensar, saibam fazer, saibam tomar atitudes diante da realidade". Já um grupo de estudantes afirmou que somente com o acesso ao ensino médio é possível "formar cidadãos decentes, que saibam seus direitos e seus deveres". ${ }^{58}$

Um segundo aspecto a ser destacado é a necessidade do ensino médio como meio para que os cidadãos possam usufruir de outros direitos fundamentais. Por exemplo, o exercício de inúmeros direitos de liberdade, como a liberdade de informação ou de expressão, o direito ao voto ou o acesso igualitário a serviços públicos requer um mínimo de educação. Além disso, diversos direitos sociais, como os direitos à escolha de profissão, a desfrutar de benefícios do progresso científico e de receber educação superior só podem ser efetivamente exercitados após o indivíduo ter atingido certo patamar de educação. Nesse contexto, o ensino médio tem um papel substancial, uma vez que somente com o acesso a essa etapa da educação básica o cidadão poderá desenvolver sua autonomia intelectual e seu pensamento crítico e, assim, efetivamente usufruir de outros direitos fundamentais. É dizer, o ensino médio confere ao indivíduo uma real capacidade de escolha. ${ }^{59}$

Outro fator a ser considerado no tocante aos fins estabelecidos ao ensino médio diz respeito à importância da compreensão dos fundamentos tecnológicos e científicos dos processos produtivos pelos cidadãos. Considerando-se as constantes mudanças socioeconômicas, tecnológicas e culturais da contemporaneidade, como consequência do "novo modelo de globalização das sociedades atuais, baseado na flexibilização e na integração dos processos de trabalho", é necessário que os cidadãos adquiram conhecimentos técnicos, mas também 
desenvolvam habilidades: (i) cognitivas, como a "capacidade de abstração, de raciocínio, de domínio de símbolos e de linguagem matemática para a leitura de modelos e antecipação de problemas, aleatórios e imprevistos"; e (ii) comportamentais, por exemplo, as capacidades de decisão, de cooperação, de responsabilidade que permitam a visualização das relações de mercado. Essas habilidades, tanto cognitivas, quanto comportamentais, só são plenamente desenvolvidas no ensino médio. ${ }^{60}$

E ainda como consequência dessas contínuas transformações, o mercado de trabalho atual reclama uma "educação mais sólida" dos indivíduos, de modo que eles estejam aptos a "transitar entre situações de emprego diversas, diante das crescentes demandas por qualificação". Para tanto, há necessidade de uma "formação continuada de competências", possibilitando que os cidadãos desenvolvam uma capacidade de aprendizado contínuo a fim de que se insiram e se mantenham em um "mercado de trabalho em constante mutação". Destarte, tal capacidade de aprendizado contínuo é desenvolvida essencialmente no ensino médio. ${ }^{61}$

Então, a partir das finalidades específicas do ensino médio na sistemática constitucional brasileira, depreende-se que esta etapa da educação básica é imprescindível para garantir aos cidadãos uma vida minimamente digna e, por conseguinte, toda a educação básica integra o mínimo existencial. Sem o ensino médio, nenhum dos objetivos da educação delineados no art. 205 da Constituição Federal poderá ser efetivamente atingido, na medida em que a educação tem por escopo: (i) desenvolver habilidades cognitivas e comportamentais do cidadão, contribuindo assim para o seu desenvolvimento pessoal; (ii) preparar os cidadãos para a cidadania; e (iii) qualificar o indivíduo para o trabalho, permitindo-lhe o desenvolvimento de autonomia intelectual e de pensamento crítico, bem como possibilitando a sua inserção e manutenção no mercado de trabalho.

Sendo assim, a posição mais acertada à luz do sistema constitucional brasileira parece ser aquela que compreende que o ensino médio consiste em posição jurídica que integra o direito ao mínimo existencial. Por consequência, a pretensão de acesso ao ensino médio é plenamente exigível pelas vias administrativa e judicial e - por fazer parte do mínimo existencial - sua proteção constitucional decorre de norma com estrutura de regra, razão pela qual sua tutela deverá ser assegurada pelo Estado de forma definitiva, sem que lhe possam ser opostos argumentos contrários aptos a afastar a sua implementação.

\section{O PODER JUDICIÁRIO E A PRETENSÃO DE ACESSO AO ENSINO MÉDIO: ANÁLISE DA JURISPRUDÊNCIA DO STF E DO TJRS}

Tendo em vista que a pretensão de acesso a todas as etapas da educação básica integra o mínimo existencial, o Poder Público tem o dever de fornecer as prestações normativas e fáticas para a realização desse direito fundamental (em 
sentido estrito). Em caso de eventual violação, seja por ação ou omissão estatal, é possível que o titular do referido direito postule-o judicialmente.

Assim, especificamente em relação à função de prestação fática do direito em questão, o cidadão poderá postular o acesso a uma vaga da rede pública de ensino ou, na impossibilidade de serem oferecidas as vagas por inexistência de condições fáticas, como a falta de estruturas físicas ou de professores, é cabível a condenação do Poder Público em arcar com os custos de uma escola da rede privada de ensino, conforme determina o artigo 213, $\S 1^{\circ}$, da Constituição Federal. ${ }^{62}$ Ademais, nessa hipótese concorda-se com Ana Paula de Barcellos acerca da necessidade de que no caso concreto sejam observados os princípios da razoabilidade e da isonomia, devendo a escola privada apresentar padrão e custos similares às escolas da rede pública. ${ }^{63}$

Diante de tais considerações, pretende-se neste tópico fazer uma breve análise do entendimento do Poder Judiciário acerca da justiciabilidade da pretensão de acesso ao ensino médio, verificando se a jurisprudência considera essa etapa da educação básica como um componente do mínimo existencial. Para tanto, foram feitos dois recortes metodológicos. Primeiro, demarcou-se temporalmente a pesquisa às decisões proferidas a partir de 01/01/2010, em razão da alteração do art. 208, I, da CF, promovida pela Emenda Constitucional no 59/2009. Em segundo lugar, delimitou-se a pesquisa às decisões proferidas: (a) pelo Supremo Tribunal Federal, por se tratar do órgão de cúpula do Poder Judiciário brasileiro, responsável por dar a última palavra a respeito da interpretação constitucional; e (b) pelo Tribunal de Justiça do Estado do Rio Grande do Sul, por se tratar de um dos tribunais com mais farta jurisprudência a respeito do assunto.

(a) No âmbito do Supremo Tribunal Federal, a pesquisa com os parâmetros "mínimo e existencial" encontrou 10 decisões, entre as quais somente o acórdão proferido no $A R E n^{\circ} 639.377$ tinha como objeto o direito fundamental à educação. ${ }^{64} \mathrm{Em}$ um segundo momento, utilizando-se os termos "ensino e médio" foram encontradas 18 decisões, as quais abordavam pretensões bastante distintas, como por exemplo a imunidade tributária de instituições de ensino de língua estrangeira ${ }^{65}$ e a possibilidade de utilização do sistema de cotas para ingresso no ensino superior. ${ }^{66}$ Entre as decisões encontradas, importa para 0 presente artigo a proferida no $\mathrm{ARE} \mathrm{n}^{\mathrm{O}} 858.084 .{ }^{67}$

Em relação à primeira decisão mencionada, proferida pelo STF no ARE $\mathrm{n}^{\mathrm{O}}$ 639.377, a pretensão postulada judicialmente dizia respeito à educação infantil, e tinha o objetivo de obrigar o Município de São Paulo a promover a matrícula de criança de até cinco anos em creche e em pré-escola em unidade da rede pública de ensino municipal. Apesar de não versar sobre acesso ao ensino médio, destaca-se essa decisão porque o Supremo Tribunal Federal reconheceu que a educação infantil integra o mínimo existencial, bem como reafirmou a possibilidade de limitação desse direito pela reserva do possível. ${ }^{68}$ 
No tocante à decisão proferida no ARE no 858.084, não houve um aprofundamento acerca da pretensão de acesso às etapas da educação básica, uma vez que foi somente desprovido o Agravo interposto pelo Estado do Maranhão. Entretanto, depreende-se da ementa que o STF reconheceu a obrigação do Estado em fornecer as prestações necessárias para garantir o acesso ao ensino fundamental e ao ensino médio, mas sem relacionar essas etapas da educação básica ao mínimo existencial.

Desse modo, infere-se que não foi possível localizar qualquer decisão do Supremo Tribunal Federal tratando do direito de acesso ao ensino médio como condição indispensável para que os indivíduos tenham uma vida minimamente digna.

(b) Em pesquisa jurisprudencial pelo sítio eletrônico do Tribunal de Justiça do Estado do Rio Grande do Sul, foram encontradas 2 decisões utilizando os termos "mínimo existencial" e "ensino", mas nenhuma útil para o trabalho.

Na sequência, foi realizada busca com os termos "vaga", "ensino médio" e "rede pública", a qual localizou 13 decisões. Após a análise dessas decisões, constatou-se que 7 tratavam sobre alguma pretensão jurídica de acesso ao ensino médio, sendo possível a classificação das referidas decisões em 3 grupos: (b.1) pretensão de acesso ao ensino médio em escola da rede pública; (b.2) pretensão de acesso à escola específica da rede pública de ensino; e (b.3) pretensão de acesso ao ensino médio na modalidade EJA - ensino supletivo.

(b.1) Duas decisões versaram sobre a pretensão de acesso à escola da rede pública de ensino. ${ }^{69} \mathrm{Em}$ ambos os casos, postulou-se a condenação do Estado membro a garantir o acesso de adolescente ao ensino médio em escola da rede pública estadual. O Tribunal de Justiça concedeu a prestação postulada nas duas ocasiões, mantendo as sentenças de primeiro grau que determinaram ao Estado a disponibilização de vaga para o estudante. Contudo, depreende-se que nenhuma das decisões aprofundou o debate acerca do direito de acesso ao ensino médio como componente do mínimo existencial, limitando-se a afirmar o dever do Estado em assegurar o acesso às três etapas da educação básica.

Tais ações merecem ainda outra observação. Infere-se que se trata de duas Ações Çivis Públicas promovidas pelo Ministério Público do Estado do Rio Grande do Sul, postulando uma vaga em escola da rede pública estadual exclusivamente em favor de um estudante. Na medida em que foi constatada a insuficiência de vagas, seria possível e adequado o ajuizamento de uma ação coletiva, com o intuito, por exemplo, de se assegurar a pretensão de acesso ao ensino médio não somente aos indivíduos que tiveram acesso ao Judiciário, ou também para se resguardar a segurança jurídica (evitando-se decisões conflitantes) e a economia processual (impedindo a proliferação de múltiplos processos individuais com objetos idênticos, com a ressalva de que foram encontradas no TJ/RS somente duas ações postulando vaga no ensino médio em escola da rede pública)..$^{70}$ 
(b.2) No segundo grupo, foram encontradas três decisões sobre a pretensão de acesso à escola específica da rede pública de ensino. ${ }^{71}$ Veja-se que nesses casos não havia falta de vaga; pelo contrário, todos os estudantes estavam devidamente matriculados em uma escola da rede pública de ensino estadual ou municipal. As três decisões negaram essa pretensão específica, ressaltando que não restou comprovado qualquer prejuízo aos indivíduos em estarem matriculados em escola diversa daquela pela qual tinham preferência.

Ainda, especificamente na $\mathrm{AC} \mathrm{n}^{\mathrm{o}} 70043068014$, o cidadão postulava a vaga em outra escola sob o fundamento de que a escola na qual estava matriculado não era a mais próxima de sua residência e, ante a inexistência de "ônibus no horário necessário para o retorno da escola" precisava caminhar até sua residência. Contudo, como foi comprovado no referido processo que o Poder Público municipal oferecia transporte escolar, a pretensão foi negada.

Nessas três decisões foi acertado o posicionamento do Tribunal de Justiça estadual, haja vista que houve o oferecimento de vaga e de transporte escolar pelo Poder Público, não sendo constatado nenhum prejuízo ou dano aos estudantes. Entretanto, novamente não se verificou qualquer manifestação do tribunal acerca do ensino médio como componente do mínimo existencial.

(b.3) No terceiro grupo, foram localizadas duas decisões ${ }^{72}$ sobre a pretensão de matrícula de estudantes com idade inferior a 18 (dezoito) anos em ensino médio supletivo, destinado aos jovens e adultos "que não tiveram acesso ou continuidade de estudos no ensino fundamental e ensino médio na idade própria", nos termos dos artigos 37 e 38, da LDB.

As duas decisões concederam a pretensão postulada judicialmente, embora com fundamentos distintos. $\mathrm{Na} A \mathrm{AC} \mathrm{n}^{\mathrm{o}}$ 70059017327, o TJ/RS entendeu que não há qualquer impedimento à matrícula de adolescentes com menos de 18 (dezoito) anos de idade em curso supletivo, sendo vedado somente que o estudante realize os exames de conclusão do ensino médio antes de atingida a maioridade civil.

Já na $\mathrm{AC} \mathrm{n}$ 70056225956, foi ressalvado que "apenas os alunos com 18 anos completos poderão se matricular na modalidade EJA", devendo adolescentes com menos de 18 (dezoito) anos de idade cursar a "modalidade regular de ensino". Contudo, como anteriormente havia sido concedida liminar determinando a matrícula do adolescente no ensino médio supletivo e a decisão foi confirmada pela sentença de primeiro grau, a decisão do tribunal manteve a sentença com o fim de não serem causados prejuízos ao estudante, "porquanto seria obrigado a repetir os conteúdos e atividades já realizadas, podendo servir de estímulo ao abandono do curso".

Referidas decisões são relevantes na medida em que buscam realizar, em última análise, a universalização do ensino médio, prevista pelo art. 208, II da CF. Porém, nos votos não foi abordado o direito ao mínimo existencial, limitando-se a Corte a afirmar que a educação básica é um direito fundamental social. 
Pela pesquisa realizada, conclui-se que não houve manifestação do Supremo Tribunal Federal ou do Tribunal de Justiça do Rio Grande do Sul sobre o ensino médio como parcela do mínimo existencial, em que pese tenha havido, em ambos os casos, reconhecimento da exigibilidade judicial dessa etapa da educação básica.

\section{CONSIDERAÇÕES FINAIS}

O direito à educação é, na sistemática constitucional brasileira, um direito fundamental, afetado pelo regime jurídico especial de proteção desses direitos e, portanto, dotado de aplicabilidade imediata e revestido da condição de cláusula pétrea. E a partir da complexa estrutura normativa que tutela o referido direito, é possível identificar posições jusfundamentais dele decorrentes que, se analisadas isoladamente, podem ser classificadas como direitos fundamentais em sentido estrito, entre as quais se destaca a pretensão de acesso aos três níveis da educação básica (educação infantil, ensino fundamental e ensino médio).

Além disso, existem algumas condições materiais que têm a finalidade de garantir aos indivíduos uma vida minimamente digna, o chamado "mínimo existencial", que corresponde ao núcleo do princípio da dignidade da pessoa humana. Assim, a fim de garantir a funcionalidade do direito ao mínimo existencial, referido direito apresenta uma estrutura normativa de regra e, por conseguinte, reclama a definição de um conteúdo específico para que sua incidência possa ocorrer de forma definitiva. Entre os direitos sociais que integram esse conteúdo destaca-se a educação, mais especificamente algumas das posições jusfundamentais compreendidas pelo direito fundamental à educação em sentido amplo.

No tocante a essas posições de direito fundamental, também denominadas de direitos fundamentais em sentido estrito, o acesso ao ensino médio deve ser considerado como integrante do mínimo existencial, pois somente nessa etapa da educação básica os indivíduos desenvolvem plenamente sua personalidade, suas habilidades cognitivas e comportamentais, sua autonomia intelectual, bem como são preparados para a cidadania e qualificados para o trabalho.

Contudo, em que pese reconhecer-se a pretensão de acesso ao ensino médio como integrante do direito ao mínimo existencial, não foi possível encontrar qualquer manifestação do Supremo Tribunal Federal ou do Tribunal de Justiça do Estado do Rio Grande do Sul neste sentido, embora se possa afirmar que ambos os tribunais, mesmo não fazendo qualquer correlação entre o ensino médio e o mínimo existencial, admitem que o acesso ao ensino médio consiste em prestação estatal ligada ao direito fundamental à educação plenamente exigível pela via judicial. 


\section{REFERÊNCIAS}

ABRAMOVAY, Miriam; CASTRO, Mary Garcia. (Coord.). Ensino médio: múltiplas vozes. Brasília: UNESCO, 2003.

ALEXY, Robert. Teoria de los derechos fundamentales. Traducción y estudio introductorio de Carlos Bernal Pulido. 2. ed. Madrid: Centros de Estudios Políticos y Constitucionales, 2007.

. Teoria dos direitos fundamentais. Tradução Virgílio Afonso da Silva. 2. ed. São Paulo: Malheiros, 2014.

BACELLAR FILHO, Romeu Felipe. Dignidade da pessoa humana, direitos fundamentais e Direito Administrativo. Revista Eurolatinoamericana de Derecho Administrativo, Santa Fe, v. 1, n. 2, p. 247-254, jul./dic. 2014.

BARCELLOS, Ana Paula de. A eficácia jurídica dos princípios constitucionais: o princípio da dignidade da pessoa humana. 3. ed. Rio de Janeiro: Renovar, 2011.

BARROSO, Luís Roberto. Fundamentos teóricos e filosóficos do novo direito constitucional brasileiro (pós-modernidade, teoria crítica e pós-positivismo). Interesse Público - IP, Belo Horizonte, ano 3, n. 11, jul./set. 2001. Disponível em: < http://bid.editoraforum.com.br/bid/PDI0006.aspx? pdiCntd=51416>. Acesso em: 12 ago. 2015.

BELÉM, Bruno Moraes Faria Monteiro. A reserva do financeiramente possível no conteúdo normativo dos direitos sociais e o constitucionalismo de cooperação. A\&C - Revista de Direito Administrativo \& Constitucional, Belo Horizonte, ano 11, n. 45, p. 229-247, jul./set. 2011.

BITENCOURT, Caroline Müller. A reserva do possível no contexto da realidade constitucional brasileira e sua aplicabilidade em relação às políticas públicas e aos direitos sociais. A\&C - Revista de Direito Administrativo \& Constitucional, Belo Horizonte, ano 14, n. 55, jan./mar. 2014. Disponível em: <http://www.bidforum.com.br/bid/PDI0006.aspx?pdiCntd=107639>. Acesso em: 12 ago. 2015.

BITENCOURT NETO, Eurico. O direito ao mínimo para uma existência digna. Porto Alegre: Livraria do Advogado Editora, 2010.

BOLESINA, Iuri; LEAL, Mônia Clarissa Hennig. O mínimo existencial e o controle de Políticas Públicas: análise de sua operacionalidade na jurisprudência do Supremo Tribunal Federal e do Superior Tribunal de Justiça. Curitiba: Multideia, 2013.

BRASIL. Instituto Brasileiro de Geografia e Estatística - IBGE. Síntese de indicadores sociais: uma análise das condições de vida da população brasileira: 2012. Rio de Janeiro: IBGE, 2012. Disponível em: < http://biblioteca.ibge.gov. br/visualizacao/livros/liv62715.pdf>. Acesso em: 23 ago. 2015. 
. Supremo Tribunal Federal. Segundo Agravo Regimental no Recurso Ordinário em Mandado de Segurança $\mathrm{n}^{\circ}$ 242.283. Relator Ministro Joaquim Barbosa. Segunda Turma, julgado em 21.09.2010, DJe-190, divulgado em 07.10.2010, publicado em 08.10.2010.

. Supremo Tribunal Federal. Agravo Regimental no Recurso Extraordinário com Agravo n ${ }^{\circ}$ 639.377. Relator Ministro Celso de Mello. Segunda Turma, julgado em 23.08.2011, DJe-177, divulgado em 14.09.2011, publicado em 15.09.2011.

. Supremo Tribunal Federal. Agravo Regimental no Recurso Extraordinário com Agravo no 858.084. Relator Ministro Marco Aurélio. Primeira Turma, julgado em 14.04.2015, DJe-083, divulgado em 05.05.2015, publicado em 06.05.2015.

. Supremo Tribunal Federal. Recurso Extraordinário n ${ }^{0}$ 597.285. Relator Ministro Ricardo Lewandowski. Tribunal Pleno, julgado em 09.05.2012, DJe053, divulgado em 17.03.2014, publicado em 18.03.2014.

. Tribunal de Justiça do Rio Grande do Sul. Agravo de Instrumento ${ }^{\circ}$ 70043068014, $7^{\text {a }}$ Câmara Cível, Desembargador Relator Sérgio Fernando de Vasconcellos Chaves, julgado em 29.06.2011.

. Tribunal de Justiça do Estado do Rio Grande do Sul. Agravo Interno no Agravo de Instrumento n ${ }^{\circ}$ 70065336521, $7^{\text {a }}$ Câmara Cível, Decisão monocrática proferida pelo Desembargador Sérgio Fernando de Vasconcellos Chaves, julgado em 24.06.2015.

. Tribunal de Justiça do Estado do Rio Grande do Sul. Apelação Cível n ${ }^{\circ}$ 70059017327, $8^{\text {a }}$ Câmara Cível, Desembargador Relator Rui Portanova, julgado em 24.04.2014.

. Tribunal de Justiça do Estado do Rio Grande do Sul. Apelação Cível $\overline{\mathrm{n}^{\circ}}$ 70056225956, Desembargador Relator Sérgio Fernando de Vasconcellos Chaves, julgado em 23.10.2013.

. Tribunal de Justiça do Estado do Rio Grande do Sul. Apelação Cível $\overline{n^{\circ}}$ 70039736830, $3^{\text {a }}$ Câmara Cível, Desembargador Relator Nelson Antônio Monteiro Pacheco, julgado em 20.11.2014.

. Tribunal de Justiça do Estado do Rio Grande do Sul. Apelação Cível $\overline{n^{\circ}} 70064537442,7^{a}$ Câmara Cível, Decisão monocrática proferida pelo Desembargador Sérgio Fernando de Vasconcellos Chaves, julgado em 10.06.2015.

. Tribunal de Justiça do Estado do Rio Grande do Sul. Apelação Cível no 70051360154, 7ª Câmara Cível, Decisão monocrática proferida pelo Desembargador Sérgio Fernando de Vasconcellos Chaves, julgado em 08.11.2012.

CALIENDO, Paulo. Direito tributário: três modos de pensar a tributação: elementos para uma teoria sistemática do direito tributário. Porto Alegre: Livraria do Advogado, 2009. 
CANOTILHO, José Joaquim Gomes. Direito constitucional e teoria da constituição. 7. ed. Coimbra: Almedina, 2003.

CARBONELL, Miguel. Los derechos sociales: elementos para una lectura en clave normativa. In: ESPINOZA DE LOS MONTEROS, Javier; ORÓÑEZ, Jorge. Los derechos sociales en el Estado Constitucional. México: Tirant lo Blanch México, 2013. p. 199-231.

CARMO, Erinaldo Ferreira; ROCHA, Enivaldo Carvalho da. A educação como direito universal. Revista Brasileira de Direito Público - RBDP, Belo Horizonte, ano 12, n. 45, p. 137-148, abr./jun. 2014.

CLÈVE, Clèmerson Merlin. O Controle de Constitucionalidade e a Efetividade dos Direitos Fundamentais. In: SAMPAIO, José Adércio Leite (Org.). Jurisdição Constitucional e Direitos Fundamentais. Belo Horizonte: Del Rey, 2003. p. 385-393.

FERREIRA, Vera Maria. A mudança possível e necessária para o ensino médio. In: AZEVEDO, José Clóvis de; REIS, Jonas Tarcísio (Org.). O ensino médio e os desafios da experiência: movimentos da prática. São Paulo: Moderna, 2014. p. 135-154.

FONTE, Felipe de Melo. Políticas públicas e direitos fundamentais: elementos de fundamentação do controle jurisdicional de políticas públicas no Estado Democrático de Direito. São Paulo: Saraiva, 2013.

GABARDO, Emerson. Interesse público e subsidiariedade: o Estado e a Sociedade Civil para além do bem e do mal. Belo Horizonte: Fórum, 2009.

GARCIA, Sandra Regina de Oliveira. Ensino médio e educação profissional: breve histórico a partir da LDBEN no 9394/96. In: AZEVEDO, José Clóvis de; REIS, Jonas Tarcísio (Org.). O ensino médio e os desafios da experiência: movimentos da prática. São Paulo: Moderna, 2014. p. 45-60.

HACHEM, Daniel Wunder. A maximização dos direitos fundamentais econômicos e sociais pela via administrativa e a promoção do desenvolvimento. Revista Direitos Fundamentais \& Democracia (UniBrasil), Curitiba, v. 13, n. 13, p. 340-399, jan./jul. 2013.

. A dupla titularidade (individual e transindividual) dos direitos fundamentais econômicos, sociais, culturais e ambientais. Revista Direitos Fundamentais \& Democracia (UniBrasil), Curitiba, v. 14, n. 14.1, p. 618-688, ago./dez. 2013.

. Mínimo existencial e direitos fundamentais econômicos e sociais: distinções e pontos de contato à luz da doutrina e jurisprudência brasileiras. In: BACELLAR FILHO, Romeu Felipe; HACHEM, Daniel Wunder (Coord.). Direito público no Mercosul: intervenção estatal, direitos fundamentais e sustentabilidade. Belo Horizonte: Fórum, 2013. p. 205-240. 
. Mínimo existencial y derechos económicos y sociales: distinciones y puntos de contacto a la luz de la doctrina y jurisprudencia brasileñas. Revista Eurolatinoamericana de Derecho Administrativo, Santa Fé - Argentina, v. 1, n. 1, p. 93-138, ene./jun. 2014.

. Tutela administrativa efetiva dos direitos fundamentais sociais: por uma implementação espontânea, integral e igualitária. 2014. 614 f. Tese (Doutorado em Direito) - Programa de Pós-Graduação em Direito, Universidade Federal do Paraná, Curitiba, 2014.

HERRÁN, Carlos; NEUBAUER, Rose (Coord.). Melhores práticas em escolas de ensino médio no Brasil. Brasília: Instituto Nacional de Estudos e Pesquisas Educacionais Anísio Teixeira, 2010.

KUENZER, Acácia Zeneida. O ensino médio no plano nacional de educação 2011-2020: superando a década perdida? Educação \& Sociedade, Campinas, v. 31, n. 112, p. 851-873, jul./set. 2010.

LEAL, Mônia Clarissa Hennig. Corte Interamericana de Direitos Humanos e jurisdição constitucional: judicialização e ativismo judicial em face da proteção dos direitos humanos e fundamentais? Revista de Investigações Constitucionais, Curitiba, v. 1, n. 3, p. 123-140, set./dez. 2014.

LOPES, Soraya Santos. O direito ao mínimo existencial no caso concreto. Interesse Público - IP, Belo Horizonte, ano 14, n. 74, jul./ago. 2012. Disponível em: < http://bid.editoraforum.com.br/bid/PDIexibepdf.aspx?tipoC onteudo $=$ Normal $\& v w=S \& p d i C n t d=81189 \& i d P u b l i c a c a o=16>$. Acesso em: 12 ago. 2015.

MENDES, Gilmar Ferreira. Direitos fundamentais e controle de constitucionalidade: estudos de direito constitucional. 4. ed. São Paulo: Saraiva, 2012.

MOZETIC, Vinicius Almada; FRANCESCHINA, Aline de Oliveira Mendes de Medeiros. A dimensão fundamental ecológica da dignidade da pessoa humana. Revista de Direito Econômico e Socioambiental, Curitiba, v. 5, n. 1, p. 161-179, jan./jun. 2014.

MUÑOZ, Jaime Rodríguez-Arana. La cláusula del Estado Social y los derechos fundamentales sociales. Revista Eurolatinoamericana de Derecho Administrativo, Santa Fé - Argentina, v. 2, n. 1, p. 155-183, ene./jun. 2015.

NEUBAUER, Rose (Coord.). Ensino médio no Brasil: uma análise de melhores práticas e de políticas públicas. Revista brasileira de estudos pedagógicos, Brasília, v. 92, n. 230, p. 11-33, abr./jan. 2011.

NOBRE JÚNIOR, Edilson Pereira. Uma ideia de Constituição. Revista de Investigações Constitucionais, Curitiba, v. 1, n. 1, p. 111-145, jan./abr. 2014.

NOVAIS, Jorge Reis. Direitos sociais: teoria jurídica dos direitos sociais enquanto direitos fundamentais. Coimbra: Coimbra Editora, 2010. 
NOWAK, Manfred. 14. The right to education. In: EIDE, Asbjorn; KRAUSE, Catarina; ROSAS, Allan. Economic, social and cultural rights. 2th ed. Dordrecht: Martinus Nijhoff Publishers, 2001. p. 245-271.

OLIVEIRA, Caio Ramon Guimarães de. Teoria do mínimo existencial como fundamento do Estado Democrático de Direito: um dialogo na busca de uma existência digna. Revista Direito e Liberdade, Natal-RN, v. 14, n. 2, p. 11-32, jul./dez. 2012.

ORGANIZAÇÃO DAS NAÇÕES UNIDAS PARA A EDUCAÇÃO, A CIÊNCIA E A CULTURA - UNESCO. Reforma da educação secundária: rumo à convergência entre a aquisição de conhecimento e o desenvolvimento de habilidade. Brasília: UNESCO, 2008.

OLSEN, Ana Carolina Lopes. A eficácia dos direitos fundamentais sociais frente à reserva do possível. 2006. 378f. Dissertação (Mestrado em Direito) - Programa de Pós-Graduação em Direito, Universidade Federal do Paraná, Curitiba, 2006.

PANSIERI, Flávio. Eficácia e vinculação dos direitos sociais: reflexões a partir do direito à moradia. São Paulo: Saraiva, 2012.

PICCINA, Guilherme Krahenbuhl Silveira Fontes. A efetividade do direito à educação básica na perspectiva do mínimo existencial na Constituição Federal. 2010. 215f. Dissertação (Mestrado em Direito) - Pontifícia Universidade Católica de São Paulo, São Paulo, 2010.

RODRIGUES, Daniel dos Santos. A defesa judicial dos direitos sociais prestacionais a partir da teoria dos direitos humanos de Amartya Sen. A\&C - Revista de Direito Administrativo e Constitucional, Belo Horizonte, ano 8, n. 34, out./dez. 2008. Disponível em: < http://www.bidforum.com.br/bid/PDI0006. aspx?pdiCntd=56003>. Acesso em: 12 ago. 2015.

SARLET, Ingo Wolfgang. A eficácia dos direitos fundamentais: uma teoria geral dos direitos fundamentais na perspectiva constitucional. 11. ed. Porto Alegre: Livraria do Advogado, 2012.

. Os direitos fundamentais como "cláusulas pétreas". Interesse Públi$\overline{\text { co - IP }}$, Belo Horizonte, n. 17, ano 5, jan./fev. 2003. Disponível em: < http:// www.bidforum.com.br/bid/PDI0006.aspx?pdiCntd=51060>. Acesso em: 12 ago. 2015.

; FIGUEIREDO, Mariana Filchtiner. Reserva do possível, mínimo existencial e direito à saúde: algumas aproximações. Revista da Defensoria Pública, ano 1, n. 1, p. 179-234, jul./dez. 2008.

SARMENTO, Daniel. A proteção judicial dos direitos sociais: alguns parâmetros ético-jurídicos. In: SOUZA NETO, Cláudio Pereira de; SARMENTO, Daniel (Coord.) Direitos sociais: fundamentos, judicialização e direitos sociais em espécie. Rio de Janeiro, Lumen Júris, 2010. p. 553-599. 
SILVA, De Plácido e. Vocabulário Jurídico. Atualizado por Nagib Salibi Filho e Priscila Pereira Vasques Gomes. 31. ed. Rio de Janeiro: Forense, 2014.

SILVA, Mônica Ribeiro. Juventudes e ensino médio: possibilidades diante das novas DCN. In: AZEVEDO, José Clóvis de; REIS, Jonas Tarcísio (Org.). O ensino médio e os desafios da experiência: movimentos da prática. São Paulo: Moderna, 2014. p. 61-75.

SOARES, Hector Cury. O controle de constitucionalidade das políticas públicas no Brasil e a importação de modelos de controle de constitucionalidade pela Constituição de 1988. Revista de Direito Econômico e Socioambiental, Curitiba, v. 2, n. 1, p. 121-150, jan./jun. 2011.

SOUZA, Elaine Ferreira de. Direito à educação: requisito para o desenvolvimento do país. São Paulo: Saraiva, 2010.

SOUZA NETO, Cláudio Pereira de. A justiciabilidade dos direitos sociais: críticas e parâmetros. In: SOUZA NETO, Cláudio Pereira de; SARMENTO, Daniel (Coord.) Direitos sociais: fundamentos, judicialização e direitos sociais em espécie. Rio de Janeiro, Lumen Júris, 2010. p. 515-551.

TORRES, Ricardo Lobo. O mínimo existencial como conteúdo essencial dos direitos fundamentais. In: SOUZA NETO, Cláudio Pereira de; SARMENTO, Daniel (Coord.) Direitos sociais: fundamentos, judicialização e direitos sociais em espécie. 2. tir. Rio de Janeiro, Lumen Júris, 2010. p. 313-339.

TOYODA, Hisashi. A apologia dos direitos humanos e a razão perversa do capitalismo: do sujeito de direito à falácia das garantias. Revista de Direito Econômico e Socioambiental, Curitiba, v. 1, n. 2, p. 333-366, jul./dez. 2010.

WANG, Daniel Wei Liang. Escassez de recursos, custos dos direitos e reserva do possível na jurisprudência do STF. Revista Direito GV, São Paulo, n. 4, v. 2, p. 539-568, jul./dez. 2008.

1 SILVA, De Plácido e. Vocabulário Jurídico. Atualizado por Nagib Salibi Filho e Priscila Pereira Vasques Gomes. 31. ed. Rio de Janeiro: Forense, 2014. p. 743. Sobre a relevância dos direitos fundamentais como elemento essencial nas Constituições, ver: NOBRE JÚNIOR, Edilson Pereira. Uma ideia de Constituição. Revista de Investigações Constitucionais, Curitiba, v. 1, n. 1, jan./abr. 2014, p. 115-117.

2 SARLET, Ingo Wolfgang. A eficácia dos direitos fundamentais: uma teoria geral dos direitos fundamentais na perspectiva constitucional. 11. ed., rev. e atual. Porto Alegre: Livraria do Advogado, 2012, p. 58. Neste sentido, ver: MENDES, Gilmar Ferreira. Direitos fundamentais e controle de constitucionalidade: estudos de direito constitucional. 4. ed., rev. e ampl. São Paulo: Saraiva, 2012. p. 468-469; MUÑOZ, Jaime Rodríguez-Arana. La cláusula del Estado Social y los derechos fundamentales sociales. Revista Eurolatinoamericana de Derecho Administrativo, Santa Fe, v. 2, n. 1, ene./jun. 2015, p. 156.

3 SARLET, Ingo Wolfgang. Os direitos fundamentais como "cláusulas pétreas". Interesse Público - IP, Belo Horizonte, n. 17, ano 5, jan./fev. 2003. Disponível em: < http://www.bidforum.com.br/bid/PDI0006. aspx?pdiCntd=51060>. Acesso em: 12 ago. 2015.

4 SARLET, Ingo Wolfgang. A eficácia..., op. cit., p. 74-75. CANOTILHO, José Joaquim Gomes. Direito constitucional e teoria da constituição. 7. ed. Coimbra: Almedina, 2003. p. 378-379.

5 HACHEM, Daniel Wunder. Mínimo existencial e direitos fundamentais econômicos e sociais: distinções e pontos de contato à luz da doutrina e jurisprudência brasileiras. In: BACELLAR FILHO, Romeu Fe- 
lipe; HACHEM, Daniel Wunder (Coord.). Direito público no Mercosul: intervenção estatal, direitos fundamentais e sustentabilidade. Belo Horizonte: Fórum, 2013. p. 206.

6 RODRIGUES, Daniel dos Santos. A defesa judicial dos direitos sociais prestacionais a partir da teoria dos direitos humanos de Amartya Sen. A\&C - Revista de Direito Administrativo e Constitucional, Belo Horizonte, ano 8, n. 34, out./dez. 2008. Disponível em: < http://www.bidforum.com.br/bid/PDI0006. aspx?pdiCntd=56003 >. Acesso em: 12 ago. 2015.

7 BITENCOURT NETO, Eurico. O direito ao mínimo para uma existência digna. Porto Alegre: Livraria do Advogado Editora, 2010. p. 154.

8 As diferenças que podem existir em relação à aplicabilidade imediata dizem respeito à função defensiva (impositiva de uma abstenção estatal) ou prestacional (impositiva de uma prestação estatal positiva) de cada direito fundamental, seja ele um direito de liberdade ou um direito social, já que todos eles possuem, simultaneamente, múltiplas funções. A função defensiva não é exclusividade dos direitos de liberdade, nem a função prestacional é exclusiva dos direitos sociais. Para um aprofundamento do tema, e com exemplos, ver: HACHEM, Daniel Wunder. Tutela administrativa efetiva dos direitos fundamentais sociais: por uma implementação espontânea, integral e igualitária. 2014. 614 f. Tese (Doutorado em Direito) - Programa de Pós-Graduação em Direito, Universidade Federal do Paraná, Curitiba, 2014. p. 129-156.

9 SARLET, Ingo Wolfgang. Os direitos fundamentais..., op. cit., s.n.

10 CANOTILHO, José Joaquim Gomes. Direito constitucional..., op. cit., p. 379.

11 SARLET, Ingo Wolfgant. A eficácia..., op. cit., p.. 68.

12 HACHEM, Daniel Wunder. A dupla titularidade (individual e transindividual) dos direitos fundamentais econômicos, sociais, culturais e ambientais. Revista Direitos Fundamentais \& Democracia (UniBrasil), Curitiba, v. 14, n. 14.1, p. 618-688, ago./dez. 2013. p. 632. Mônia Clarissa Hennig Leal ressalta a importância do Judiciário para concretização dos direitos fundamentais quando houver eventual ação ou omissão do Executivo ou do Legislativo implicarem violação destes direitos. Cf.: LEAL, Mônia Clarissa Hennig. Corte Interamericana de Direitos Humanos e jurisdição constitucional: judicialização e ativismo judicial em face da proteção dos direitos humanos e fundamentais? Revista de Investigações Constitucionais, Curitiba, v. 1, n. 3, set./dez. 2014, p. 126-128.

13 SARLET, Ingo Wolfgang. A eficácia..., op. cit., p. 152.

14 SARLET, Ingo Wolfgang. A eficácia..., op. cit., p. 146. Semelhante é o posicionamento de Jaime Rodríguez-Arana Muñoz, para quem o Estado deve criar as condições necessárias para permitir a todos os cidadãos o exercício dos direitos fundamentais. Cf.: MUÑOZ, Jaime Rodriguez-Arana. Lá cláusula..., op. cit., p. 163. Já Romeu Felipe Bacellar Filho atenta para a necessidade de uma Administração Pública "protetora, que desempenha atividades administrativas para promoção e efetivação dos direitos fundamentais". Cf.: BACELLAR FILHO, Romeu Felipe. Dignidade da pessoa humana, direitos fundamentais e Direito Administrativo. Revista Eurolatinoamericana de Derecho Administrativo, Santa Fé - Argentina, v. 1, n. 2, jul./dic. 2014, p. 248.

15 Estas terminologias são utilizadas por Robert Alexy. Na versão traduzida para o português foi utilizada a expressão "direito fundamental completo", ao passo que na versão traduzida para o espanhol foi empregada a expressão "derecho fundamental como un todo". Cf.: ALEXY, Robert. Teoria dos direitos fundamentais. Tradução Virgílio Afonso da Silva. 2. ed., 3. tir. São Paulo: Malheiros, 2014, passim; ALEXY, Robert. Teoria de los derechos fundamentales. Traducción y estudio introductorio de Carlos Bernal Pulido. 2. ed. Madrid: Centros de Estudios Políticos y Constitucionales, 2007, passim.

16 HACHEM, Daniel Wunder. Tutela administrativa..., op. cit., p. 32-33. SARLET, Ingo Wolfgang. A eficácia..., op. cit., p. 155-156.

17 ALEXY, Robert. Teoria dos direitos..., op. cit., p. 249.

18 ALEXY, Rober. Teoria dos direitos..., op. cit., p. 196-203; SARLET, Ingo Wolfgang. A eficácia..., op. cit., p. 167.

19 CARBONELL, Miguel. Los derechos sociales: elementos para una lectura en clave normativa. In: ESPINOZA DE LOS MONTEROS, Javier; ORÓÑEZ, Jorge. Los derechos sociales en el Estado Constitucional. México: Tirant lo Blanch México, 2013. p. 220.

20 HACHEM, Daniel Wunder. Tutela administrativa..., op. cit., p. 131.

21 ALEXY, Robert. Teoria dos direitos..., op. cit., p. 442.

22 Em sentido similar: BERNAL PULIDO, Carlos. El principio de proporcionalidad y los derechos fundamentales. 3. ed. Madrid: Centro de Estudios Políticos y Constitucionales, 2007. p. 81-82.

23 CALIENDO, Paulo. Direito tributário: três modos de pensar a tributação - elementos para uma teoria sistemática do direito tributário. Porto Alegre: Livraria do Advogado, 2009, p. 25; GABARDO, Emerson. 
Interesse público e subsidiariedade: o Estado e a Sociedade Civil para além do bem e do mal. Belo Horizonte: Fórum, 2009. p. 331.

24 BARCELLOS, Ana Paula de. A eficácia jurídica dos princípios constitucionais: o princípio da dignidade da pessoa humana. 3. ed., rev. e atual. Rio de Janeiro: Renovar, 2011. p. 31; CLÈVE, Clèmerson Merlin. O Controle de Constitucionalidade e a Efetividade dos Direitos Fundamentais. In: SAMPAIO, José Adércio Leite (Org.). Jurisdição Constitucional e Direitos Fundamentais. Belo Horizonte: Del Rey, 2003, p. 388.

25 HACHEM, Daniel Wunder. Mínimo existencial e direitos fundamentais..., op. cit., p. 211. Neste sentido, Ana Paula de Barcellos afirma que não é possível precisar toda a extensão e todos os efeitos que decorrem do princípio da dignidade da pessoa humana, mas somente um conteúdo mínimo. CF: BARCELLOS, Ana Paula de. A eficácia jurídica..., op. cit., p. 242.

26 BARCELLOS, Ana Paula de. A eficácia jurídica..., op. cit., p. 299; TORRES, Ricardo Lobo. O mínimo existencial como conteúdo essencial dos direitos fundamentais. In: SOUZA NETO, Cláudio Pereira de; SARMENTO, Daniel (Coord.) Direitos sociais: fundamentos, judicialização e direitos sociais em espécie. 2. tir. Rio de Janeiro, Lumen Júris, 2010. p. 315-316.

27 BARCELLOS, Ana Paula de. A eficácia jurídica..., op. cit., p. 247.

28 SARMENTO, Daniel. A proteção judicial dos direitos sociais: alguns parâmetros ético-jurídicos. In: SOUZA NETO, Cláudio Pereira de; SARMENTO, Daniel (Coord.) Direitos sociais: fundamentos, judicialização e direitos sociais em espécie. 2. tir. Rio de Janeiro, Lumen Júris, 2010. p. 576. Essa dupla dimensão também é afirmada por Eurico Bitencourt Neto. Cf: BITENCOURT NETO, Eurico. O direito..., op. cit., p. 124-126. Como exemplos da dimensão negativa, Ricardo Lobo Torres menciona a proibição de tributação das condições mínimas para uma existência digna. Cf: TORRES, Ricardo Lobo. O mínimo existencial..., op. cit., p.314.

29 HACHEM, Daniel Wunder. A maximização dos direitos fundamentais econômicos e sociais pela via administrativa e a promoção do desenvolvimento. Revista Direitos Fundamentais \& Democracia (UniBrasil), Curitiba, v. 13, n. 13, jan./jul. 2013, p. 356-369.

30 BARROSO, Luís Roberto. Fundamentos teóricos e filosóficos do novo direito constitucional brasileiro (pós-modernidade, teoria crítica e pós-positivismo). Belo Horizonte, Interesse Público - IP, ano 3, n. 11, jul./ set. 2001. Disponível em: <http://bid.editoraforum.com.br/bid/PDI0006.aspx?pdiCntd=51416>. Acesso em: 12 ago. 2015.

31 BARCELLOS, Ana Paula de. A eficácia jurídica..., op. cit., p. 247; HACHEM, Daniel Wunder. Mínimo existencial y derechos económicos y sociales: distinciones y puntos de contacto a la luz de la doctrina y jurisprudencia brasileñas. Revista Eurolatinoamericana de Derecho Administrativo, Santa Fé - Argentina, v. 1, n. 1, ene./jun. 2014, p. 101-102; SARLET, Ingo Wolfgang. A eficácia..., op. cit., p. 320. Já Vinicius Almada Mozetic e Aline Oliveira Mendes de Medeiros Franceschina vão além e sustentam a existência de uma dimensão ecológica integrando o cerne da dignidade da pessoa humana, de modo que o meio ambiente deve ser considerado um "fator indispensável para a sadia qualidade da existência". Cf.: MOZETIC, Vinicius Almada; FRANCESCHINA, Aline de Oliveira Mendes de Medeiros. A dimensão fundamental ecológica da dignidade da pessoa humana. Revista de Direito Econômico e Socioambiental, Curitiba, v. 5, n. 1, jan.jun. 2014, p. 172.

32 Conforme exposto no tópico 1, entende-se que todos os direitos fundamentais são dotados de aplicabilidade imediata e, portanto, podem ser exigidos administrativa ou judicialmente.

33 ALEXY, Robert. Teoria dos direitos..., op. cit., p. 90-91.

34 Conforme Jorge Reis Novais, as três reservas que afetam os direitos fundamentais são: (i) reserva geral imanente da ponderação, no tocante aos deveres estatais de respeito e de prestação; (ii) reserva do politicamente adequado ou oportuno no tocante aos deveres de proteção e promoção, pois a Administração possui legitimidade e discricionariedade para escolher qual a melhor alternativa a ser adotada; e (iii) reserva do financeiramente possível em relação à faceta prestacional dos direitos fundamentais. Cf: NOVAIS, Jorge Reis. Direitos sociais: teoria jurídica dos direitos sociais enquanto direitos fundamentais. Coimbra: Coimbra Editora, 2010, p. 152.

35 BARCELLOS, Ana Paula de. A eficácia jurídica..., op. cit., p. 243; OLIVEIRA, Caio Ramon Guimarães de. Teoria do mínimo existencial como fundamento do Estado Democrático de Direito: um diálogo na busca de uma existência digna. Revista Direito e Liberdade, Natal, v. 14, n. 2, jul./dez. 2012, p. 19-20; HACHEM, Daniel Wunder. A maximização dos direitos fundamentais..., op. cit., p. 364-365.

36 BOLESINA, Iuri; LEAL, Mônia Clarissa Hennig. O mínimo existencial e o controle de Políticas Públicas: análise de sua operacionalidade na jurisprudência do Supremo Tribunal Federal e do Superior 
Tribunal de Justiça. Curitiba: Multideia, 2013. 89-93. Sobre a distinção entre reserva do possível como "teoria dos custos" e como "critério de razoabilidade" na jurisprudência brasileira, ver: BITENCOURT, Caroline Müller. A reserva do possível no contexto da realidade constitucional brasileira e sua aplicabilidade em relação às políticas públicas e aos direitos sociais. $\mathrm{A \& C}$ - Revista de Direito Administrativo $\&$ Constitucional, Belo Horizonte, ano 14, n. 55, jan./mar. 2014.

37 BOLESINA, Iuri; LEAL, Mônia Clarissa Hennig. O mínimo existencial..., op. cit., p. 98. Veja-se que para os autores é necessário ponderar a razoabilidade e proporcionalidade de uma pretensão a partir das singularidades do caso concreto. Contudo, os autores citam como exemplo as ações judiciais que postulam medicamentos de alto custo. Como não é objeto desse artigo discorrer acerca do direito à saúde, registra-se concordância com o posicionamento de Ana Paula de Barcellos, para quem a determinação do mínimo existencial no tocante à saúde cinge-se à saúde básica. Cf: BARCELLOS, Ana Paula de. A eficácia jurídica..., op. cit., p. 320-337.

38 BOLESINA, Iuri; LEAL, Mônia Clarissa Hennig. O mínimo existencial..., op. cit., p. 99.

39 Em sentido contrário, entendendo que a reserva do financeiramente possível (dimensão fática) pode limitar a exigibilidade do direito ao mínimo existencial, ver: SARLET, Ingo Wolfgang; FIGUEIREDO, Mariana Filchtiner. Reserva do possível, mínimo existencial e direito à saúde: algumas aproximações. Revista da Defensoria Pública, ano 1, n. 1, jul./dez. 2008, p. 198; SARMENTO, Daniel. A proteção judicial dos direitos sociais..., op. cit., p. 5578-579.

40 Robert Alexy exemplifica a variação no tempo do conteúdo do mínimo existencial em um mesmo país, ao afirmar que "sob a Constituição alemã, o que importa é o mínimo existencial relativo, ou seja, aquilo que sob as condições de cada momento na República Federal da Alemanha seja considerado como mínimo existencial”. ALEXY, Robert. Teoria dos direitos..., op. cit., p. 427-428. Já Hisashi Toyoda, em análise histórica crítica sobre o surgimento dos direitos humanos como um produto do capitalismo, salienta que a "ideia de direitos inerentes à condição humana é em si mesma produto do pensamento em determinado momento e em um contexto sociocultural específico, e como tal pode ser interpretada à luz de um processo histórico, de uma realidade objetiva". Cf.: TOYODA, Hisashi. A apologia dos direitos humanos e a razão perversa do capitalismo: do sujeito de direito à falácia das garantias. Revista de Direito Econômico e Socioambiental, Curitiba, v. 1, n. 2, jul./dez. 2010, p. 348.

41 BITENCOURT NETO, Eurico. O direito..., op. cit., p. 119.

42 BITENCOURT NETO, Eurico. O direito..., op. cit., p. 119. É também o entendimento de Ingo Wolfgang Sarlet e Mariana Filchtiner Figueiredo, segundo os quais há necessidade de se avaliar as necessidades de cada pessoa (e, se for o caso, de seu núcleo familiar) para se identificar o que compõe o mínimo existencial. Cf.: SARLET, Ingo Wolfgang; FIGUEIREDO, Mariana Filchtiner. Reserva do possível..., op. cit., p. 198. Na mesma linha, Ana Carolina Lopes Olsen aduz que o "mínimo existencial, como a porção nuclear do direito fundamental necessária à sobrevivência com dignidade do seu titular, pode ser identificado em cada caso concreto". Cf.: OLSEN, Ana Carolina Lopes. A eficácia dos direitos fundamentais sociais frente à reserva do possível. 2006. 378f. Dissertação (Mestrado em Direito) - Programa de Pós-Graduação em Direito, Universidade Federal do Paraná, Curitiba, 2006. p. 354.

43 NOVAIS, Jorge Reis. Direitos sociais..., op. cit., p. 159.

44 NOVAIS, Jorge Reis. Direitos sociais..., op. cit., p. 160-176. Neste sentido, ver também: HACHEM, Daniel Wunder. Tutela administrativa..., op. cit., p. 142-144 e 155-156.

45 A redação original do art. 208, I prescrevia que o Estado tinha o dever de garantir o "ensino fundamental, obrigatório e gratuito, inclusive para os que a ele não tiveram acesso na idade própria". E antes da EC n ${ }^{\circ}$ 59/2009, o referido inciso havia sido alterado pela $E C n^{\circ}$ 14/1996 e tinha a seguinte redação: "I - ensino fundamental, obrigatório e gratuito, assegurada, inclusive, sua oferta gratuita para todos os que a ele não tiveram acesso na idade própria".

46 A expressão "educação secundária" não é utilizada pela Constituição Federal ou pela LDB. Por esta razão, salienta-se que a educação secundária compreende os quatro últimos anos do ensino fundamental e o ensino médio. Cf: ORGANIZAÇÃO DAS NAÇÕES UNIDAS PARA A EDUCAÇÃO, A CIÊNCIA E A CULTURA - UNESCO. Reforma da educação secundária: rumo à convergência entre a aquisição de conhecimento e o desenvolvimento de habilidade. Brasília: UNESCO, 2008. p. 11.

47 BARCELlOS, Ana Paula de. A eficácia jurídica..., op. cit., passim; BARROSO, Luís Roberto. Fundamentos teóricos..., op. cit., s.n.; BITENCOURT NETO, Eurico. O direito..., op. cit., passim; CARMO, Erinaldo Ferreira; ROCHA, Enivaldo Carvalho da. A educação como direito universal. Revista Brasileira de Direito Público - RBDP, Belo Horizonte, ano 12, n. 45, abr./jun. 2014, p. 142; HACHEM, Daniel Wunder. Mínimo existencial y derechos..., op. cit., passim; LOPES, Soraya Santos. O direito ao 
mínimo existencial no caso concreto. Interesse Público - IP, Belo Horizonte, ano 14, n. 74, jul./ago. 2012. Disponível em: <http://bid.editoraforum.com.br/bid/PDlexibepdf.aspx?tipoConteudo=Normal\& $\mathrm{vw}=$ S\&pdiCntd $=81189 \&$ \&idPublicacao $=16>$. Acesso em: 12 ago. 2015; PANSIERI, Flávio. Eficácia e vinculação dos direitos sociais: reflexões a partir do direito à moradia. São Paulo: Saraiva, 2012. p. 55; SARLET, Ingo Wolfgang. A eficácia..., op. cit., p. 322; TORRES, Ricardo Lobo. O mínimo existencial..., op. cit., 330.

48 SOUZA NETO, Cláudio Pereira de. A justiciabilidade dos direitos sociais: críticas e parâmetros. In: SOUZA NETO, Cláudio Pereira de; SARMENTO, Daniel (Coord.) Direitos sociais: fundamentos, judicialização e direitos sociais em espécie. 2. tir. Rio de Janeiro, Lumen Júris, 2010. p. 538; SOUZA, Elaine Ferreira de. Direito à educação: requisito para o desenvolvimento do país. São Paulo: Saraiva, 2010. p. 26; FONTE, Felipe de Melo. Políticas públicas e direitos fundamentais: elementos de fundamentação do controle jurisdicional de políticas públicas no Estado Democrático de Direito. São Paulo: Saraiva, 2013. p. 211-213; OLIVEIRA, Caio Ramon Guimarães de. Teoria do mínimo existencial..., op. cit., p. 30; BOLESINA, Iuri; LEAL, Mônia Clarissa Hennig. O mínimo existencial..., op. cit., passim; CARMO, Erinaldo Ferreira; ROCHA, Enivaldo Carvalho da. A educação..., op. cit., p. 145.

49 É o caso de Cláudio Pereira de Souza Neto, Elaine Ferreira de Souza e Felipe de Melo Fonte, citados na nota anterior. No caso de Cláudio Pereira de Souza Neto, no entanto, é preciso fazer um esclarecimento: o autor, embora entenda que o mínimo existencial em matéria de educação engloba apenas o acesso até o ensino fundamental, sustenta que o acesso ao ensino médio também é exigível judicialmente, ainda que não integre o mínimo existencial. Isso porque, de acordo com a sua posição teórica, a exigibilidade judicial dos direitos sociais não se limita às suas parcelas que integram o mínimo existencial: tais direitos seriam sindicáveis perante o Poder Judiciário em relação a todas as prestações necessárias para proporcionar as condições procedimentais da deliberação pública democrática. De acordo com o seu entendimento, o acesso ao ensino médio, ainda que não consista em uma prestação imprescindível para se viver de forma minimamente digna, revela-se uma condição indispensável para a participação nas instâncias de deliberação pública. SOUZA NETO, Cláudio Pereira de. A justiciabilidade dos..., op. cit., p. 537-546.

50 BARCELLOS, Ana Paula de. A eficácia jurídica..., op. cit., p. 303-319; PICCINA, Guilherme Krahenbuhl Silveira Fontes. A efetividade do direito à educação básica na perspectiva do mínimo existencial na Constituição Federal. 2010. 215f. Dissertação (Mestrado em Direito) - Pontifícia Universidade Católica de São Paulo, São Paulo, 2010. p. 150-162.

51 BARCELlOS, Ana Paula de. A eficácia jurídica..., op. cit., p. 304-307.

52 Ibidem, p. 308-309.

53 BRASIL. Instituto Brasileiro de Geografia e Estatística - IBGE. Síntese de indicadores sociais: uma análise das condições de vida da população brasileira: 2012. Rio de Janeiro: IBGE, 2012, p. 115-116. Disponível em: < http://biblioteca.ibge.gov.br/visualizacao/livros/liv62715.pdf>. Acesso em 23 ago. 2015. Também neste sentido, Acácia Zeneida Kuenzer demonstra que o número de matrículas de jovens e adultos no ensino médio decresceu no período compreendido entre 2000 e 2010. Cf.: KUENZER, Acácia Zeneida. O ensino médio no plano nacional de educação 2011-2020: superando a década perdida? Educação \& Sociedade, Campinas, v. 31, n. 112, p. 854-862, jul./set. 2010. Já Sandra Regina de Oliveira Garcia atenta para a carente oferta de acesso ao ensino médio no período noturno, o que prejudica o acesso a este nível da educação básica. Cf.: GARCIA, Sandra Regina de Oliveira. Ensino médio e educação profissional: breve histórico a partir da LDBEN n 9394/96. In: AZEVEDO, José Clóvis de; REIS, Jonas Tarcísio (Org.). O ensino médio e os desafios da experiência: movimentos da prática. São Paulo: Moderna, 2014. p. 52-53.

54 PICCINA, Guilherme Krahenbuhl Silveira Fontes. A efetividade do direito..., op. cit., p. 151-152.

55 Lei no 9.394/1996. Art. 35. O ensino médio, etapa final da educação básica, com duração mínima de três anos, terá como finalidades: I - a consolidação e o aprofundamento dos conhecimentos adquiridos no ensino fundamental, possibilitando o prosseguimento de estudos; II - a preparação básica para o trabalho e a cidadania do educando, para continuar aprendendo, de modo a ser capaz de se adaptar com flexibilidade a novas condições de ocupação ou aperfeiçoamento posteriores; III - o aprimoramento do educando como pessoa humana, incluindo a formação ética e o desenvolvimento da autonomia intelectual e do pensamento crítico; IV - a compreensão dos fundamentos científico-tecnológicos dos processos produtivos, relacionando a teoria com a prática, no ensino de cada disciplina.

56 Lei no 9.394/1996. Art. 29. A educação infantil, primeira etapa da educação básica, tem como finalidade o desenvolvimento integral da criança de até 5 (cinco) anos, em seus aspectos físico, psicológico, intelectual e social, complementando a ação da família e da comunidade. 
57 Lei no 9.394/1996. Art. 32. O ensino fundamental obrigatório, com duração de 9 (nove) anos, gratuito na escola pública, iniciando-se aos 6 (seis) anos de idade, terá por objetivo a formação básica do cidadão, mediante: I - o desenvolvimento da capacidade de aprender, tendo como meios básicos o pleno domínio da leitura, da escrita e do cálculo; II - a compreensão do ambiente natural e social, do sistema político, da tecnologia, das artes e dos valores em que se fundamenta a sociedade; III - o desenvolvimento da capacidade de aprendizagem, tendo em vista a aquisição de conhecimentos e habilidades e a formação de atitudes e valores; IV - o fortalecimento dos vínculos de família, dos laços de solidariedade humana e de tolerância recíproca em que se assenta a vida social.

58 ABRAMOVAY, Miriam; CASTRO, Mary Garcia. (Coord.). Ensino médio: múltiplas vozes. Brasília: UNESCO, 2003. p. 162-163.

59 NOWAK, Manfred. 14. The right to education. In: EIDE, Asbjorn; KRAUSE, Catarina; ROSAS, Allan. Economic, social and cultural rights. 2th ed. Dordrecht: Martinus Nijhoff Publishers, 2001. p. 245-253. Semelhante é o posicionamento de Vera Maria Ferreira, para quem a educação básica deve ser concebida como um processo que viabiliza ao cidadão a possibilidade de optar pelas "escolhas mais qualificadas, tanto do ponto de vista individual quanto do coletivo". Cf.: FERREIRA, Vera Maria. A mudança possível e necessária para o ensino médio. In: AZEVEDO, José Clóvis de; REIS, Jonas Tarcísio (Org.). O ensino médio e os desafios da experiência: movimentos da prática. São Paulo: Moderna, 2014. p. 139.

60 NEUBAUER, Rose (Coord.). Ensino médio no Brasil: uma análise de melhores práticas e de políticas públicas. Revista brasileira de estudos pedagógicos, Brasília, v. 92, n. 230, p. 12 abr.jjan. 2011. Também neste sentido, ver: SILVA, Mônica Ribeiro. Juventudes e ensino médio: possibilidades diante das novas DCN. In: AZEVEDO, José Clóvis de; REIS, Jonas Tarcísio (Org.). O ensino médio e os desafios da experiência: movimentos da prática. São Paulo: Moderna, 2014. p. 62-65.

61 HERRÁN, Carlos; NEUBAUER, Rose (Coord.). Melhores práticas em escolas de ensino médio no Brasil. Brasília: Instituto Nacional de Estudos e Pesquisas Educacionais Anísio Teixeira, 2010. p. 34. Já Miriam Abramovay e Mary Garcia Castro afirmam que no atual contexto histórico internacional e nacional, o qual demanda "uma maior e mais sofisticada escolaridade", é imperativo o acesso ao ensino médio. Cf.: ABRAMOVAY, Miriam; CASTRO, Mary Garcia. (Coord.). Ensino médio..., op. cit., p. 152.

62 HACHEM, Daniel Wunder. Mínimo existencial y derechos..., op. cit., p. 110.

63 BARCELLOS, Ana Paula de. A eficácia..., op. cit., p. 312.

64 BRASIL. Supremo Tribunal Federal. Agravo Regimental no Recurso Extraordinário com Agravo no 639.377. Relator Ministro Celso de Mello. Segunda Turma, julgado em 23.08.2011, DJe-177, divulgado em 14.09.2011, publicado em 15.09.2011.

65 BRASIL. Supremo Tribunal Federal. Segundo Agravo Regimental no Recurso Ordinário em Mandado de Segurança $n^{\circ}$ 242.283. Relator Ministro Joaquim Barbosa. Segunda Turma, julgado em 21.09.2010, DJe-190, divulgado em 07.10.2010, publicado em 08.10.2010.

66 BRASIL. Supremo Tribunal Federal. Recurso Extraordinário no 597.285. Relator Ministro Ricardo Lewandowski. Tribunal Pleno, julgado em 09.05.2012, DJe-053, divulgado em 17.03.2014, publicado em 18.03.2014.

67 BRASIL. Supremo Tribunal Federal. Agravo Regimental no Recurso Extraordinário com Agravo n ${ }^{\circ}$ 858.084. Relator Ministro Marco Aurélio. Primeira Turma, julgado em 14.04.2015, DJe-083, divulgado em 05.05.2015, publicado em 06.05.2015.

68 Em estudo jurisprudencial realizado em 2008, Daniel Wei Liang Wang havia demonstrado o entendimento do STF em relação à educação infantil como componente do mínimo existencial. Ainda, o autor destacou que a Suprema Corte se limitava a condenar o Poder Público a dar acesso a uma vaga em creche e pré-escola, porém sem uma análise mais detida acerca do tema da reserva do possível. Cf.: WANG, Daniel Wei Liang. Escassez de recursos, custos dos direitos e reserva do possível na jurisprudência do STF. Revista Direito GV, São Paulo, n. 4, v. 2, p. 552-558, jul./dez. 2008.

69 BRASIL. Tribunal de Justiça do Estado do Rio Grande do Sul. Apelação Cível n ${ }^{\mathrm{o}} 70064537442$, $7^{\text {a }}$ Câmara Cível, Decisão monocrática proferida pelo Desembargador Sérgio Fernando de Vasconcellos Chaves, julgado em 10.06.2015; BRASIL, Tribunal de Justiça do Estado do Rio Grande do Sul. Apelação Cível n ${ }^{\circ} 70051360154,7^{\text {a }}$ Câmara Cível, Decisão monocrática proferida pelo Desembargador Sérgio Fernando de Vasconcellos Chaves, julgado em 08.11.2012.

70 Acerca do controle de políticas públicas em ações coletivas, ver: SOARES, Hector Cury. O controle de constitucionalidade das políticas públicas no Brasil e a importação de modelos de controle de constitucionalidade pela Constituição de 1988. Revista de Direito Econômico e Socioambiental, Curitiba, v. 2, n. 1, p. 121-150, jan./jun. 2011. 
71 BRASIL. Tribunal de Justiça do Estado do Rio Grande do Sul. Agravo Interno no Agravo de Instrumento n ${ }^{\circ} 70065336521,7^{a}$ Câmara Cível, Decisão monocrática proferida pelo Desembargador Sérgio Fernando de Vasconcellos Chaves, julgado em 24.06.2015; BRASIL. Tribunal de Justiça do Estado do Rio Grande do Sul. Apelação Cível n ${ }^{\circ} 70039736830,3^{a}$ Câmara Cível, Desembargador Relator Nelson Antônio Monteiro Pacheco, julgado em 20.11.2014; BRASIL. Tribunal de Justiça do Rio Grande do Sul. Agravo de Instrumento n ${ }^{\circ} 70043068014,7^{\text {a }}$ Câmara Cível, Desembargador Relator Sérgio Fernando de Vasconcellos Chaves, julgado em 29.06.2011.

72 BRASIL. Tribunal de Justiça do Estado do Rio Grande do Sul. Apelação Cível no 70059017327 , $8^{\text {a }}$ Câmara Cível, Desembargador Relator Rui Portanova, julgado em 24.04.2014; BRASIL. Tribunal de Justiça do Estado do Rio Grande do Sul. Apelação Cível no 70056225956 , Desembargador Relator Sérgio Fernando de Vasconcellos Chaves, julgado em 23.10.2013.

\title{
HIGH SCHOOL EDUCATION AS PART OF THE RIGHT TO THE EXISTENTIAL MINIMUM
}

\begin{abstract}
This article aims to analyze whether high school education, the third stage of basic education, is part of the right to the existential minimum. To that purpose, the paper analyzes the normative structure and the system of protection of the fundamental right to education. Afterwards, it presents a definition of the right to the existential minimum, identifying that its normative structure is one of rules, thus unsusceptible to balancing. Then, in view of the need to define the content of the existential minimum, the paper analyzes different theories regarding which positions of the fundamental right to education are a part of the existential minimum, concluding that, according to the Brazilian Constitution, the purposes and relevance of high school education make this stage of education essential to ensuring the dignity of the human person. Finally, the article examines the understanding of the Judiciary, through decisions by the Brazilian Supreme Court and by the Court of Justice of the State of Rio Grande do Sul, regarding high school education as part of the existential minimum.
\end{abstract}

Keywords: Fundamental rights. Social rights. Existential minimum. Basic education. High school education.

Submetido: 10 jun. 2016

Aprovado: 28 jun. 2016 